\title{
Going Green Supply Chain Management During COVID-19, Assessing the Best Supplier Selection Criteria: A Triple Bottom Line (TBL) Approach
}

\author{
W kierunku zrównoważonego zarządzania łańcuchami \\ dostaw podczas pandemii COVID-19, ocena kryteriów \\ wyboru najlepszych dostawców: analiza Potrójnej Linii \\ Przewodniej (TBL)
}

\section{Maryam Khokhar*, Sayma Zia**, Tahir Islam**, Anshuman Sharma ${ }^{\star \star \star \star}$, Wasim Iqbal ${ }^{\star \star \star \star \star}$, Muhammad Irshad ${ }^{\star \star \star \star \star \star}$}

\author{
* School of Economics and Management Yanshan University, China \\ ** Bahria Business School, Department of Business Studies, Bahria \\ University Karachi Campus, Karachi, Pakistan \\ *** Dept. of Management, Faculty of Management, Prague University of Economics and Business, Czech \\ Republic \\ **** Ajman University, Department of Marketing, College of Business Administration, \\ United Arab Emirates \\ ***** Shenzhen University, Department of Management Science, College of Management, China \\ ****** Yanshan University, College of Computer Science and Technology, China \\ E-mails:*maryamkhokhar@stumail.ysu.edu.cn,**pbbs.buke@bahria.edu.pk, \\ ***kktahir@hotmail.com,****profasharma@gmail.com,*****wasimiqbal01@yahoo.com, \\ ******ibrahim@stumail.ysu.edu.cn \\ ****(Corresponding Author) maryamkhokhar@stumail.ysu.edu.cn
}

\begin{abstract}
In the past ten years, sustainable supply chain management (SSCM) attach great importance due to consumers, for-profit and profitless organizations, laws and regulations to the social and corporate responsibilities of consumers, so it has been recognized by practitioners and scholars. Supplier selection, environmental effect like a lockdown, and social cooperation and other SSCM programs can play an important part in realizing the triple bottom line (TBL) of economic, environmental, social assistances. In supply chain management (SCM), the sustainable supplier selection (SSS) and firm performance plays an important role. Traditionally, when evaluating SSS performance, organizations will consider a new framework to obtain the overall criteria/sub-criteria of the sustainability index by encapsulating sustainability. In this paper 12 sub-criteria for 3 pillars of sustainability as economic, environment and social performance is collected. Although there are many articles on SSS and evaluation, so far, research on sustainability issues is very limited. This study endeavours to propose a fuzzy multi-criteria approach to discuss SSCM planning, and studies the issue of determining a current model for SSS in the supply chain during COVID-19 based on the TBL method. For express the linguistic value of the subjective preference of experts we use triangular fuzzy numbers. By using fuzzy numbers to find standard weights for qualitative performance evaluation, then fuzzy TOPSIS (Technique for Order Preference by Similarity to Ideal Solution) is proposed to find the ranking of SSS. However, COVID-19 has a negative role in SSS and in firm performance. The situation of lockdown due to COVID-19 has a negative effect on the performance of the organizations. An example is given of the proposed method.
\end{abstract}

Key words: sustainable supply chain management (SSCM), triple bottom line (TBL), sustainable supplier selection (SSS), Technique for Order Preference by Similarity to Ideal Solution (TOPSIS), COVID-19

\section{Streszczenie}

Zrównoważone zarządzanie łańcuchem dostaw (SSCM) staje się coraz bardziej istotne w kontekście konsumentów, organizacji nastawionych na zysk i organizacji bez zysku oraz przepisy ustawowe i wykonawcze do społecznej i korporacyjnej odpowiedzialności konsumentów. Zostało docenione przez praktyków i naukowców. Wybór dostawcy, efekt środowiskowy, taki jak 
blokada, oraz współpraca społeczna i inne programy SSCM mogą odgrywać ważną rolę w realizacji Potrójnej linii przewodniej (TBL) pomocy ekonomicznej, środowiskowej i społecznej. W zarządzaniu łańcuchem dostaw (SCM) zrównoważony wybór dostawców (SSS) i wydajność firmy odgrywają ważną rolę. Tradycyjnie, podczas oceny wyników SSS, organizacje będą rozważać nowe ramy w celu uzyskania ogólnych kryteriów/podkryteriów indeksu rozwoju, poprzez enkapsulację zrównoważonego rozwoju. W niniejszym artykule zebrano 12 kryteriów cząstkowych dla 3 filarów zrównoważonego rozwoju, takich jak wyniki gospodarcze, środowiskowe i społeczne. Chociaż istnieje wiele artykułów na temat SSS i ewaluacji, jak dotąd badania dotyczące kwestii zrównoważonego rozwoju są bardzo ograniczone. Niniejsze badanie ma na celu zaproponowanie rozmytego, wielokryterialnego podejścia do omówienia planowania SSCM i bada kwestię określenia obecnego modelu SSS w łańcuchu dostaw podczas COVID-19 w oparciu o metodę TBL. Aby wyrazić wartość językową subiektywnej preferencji ekspertów, używamy trójkątnych liczb rozmytych. Stosując liczby rozmyte do znalezienia standardowych wag do jakościowej oceny wydajności, proponuje się następnie rozmyte TOPSIS (Technika uporządkowania preferencji według podobieństwa do idealnego rozwiązania) w celu znalezienia rankingu SSS. Stwierdzono, że pandemia COVID-19 wywiera negatywny wpływ na SSS i wydajność firmy. Sytuacja zablokowania z powodu pandemii COVID-19 także ma negatywny wpływ na wyniki organizacji. Pomoc stanowi nowa metoda, analizowana w niniejszym artykule.

Słowa kluczowe: Zrównoważone zarządzanie łańcuchem dostaw, SSCM, Potrójna linia przewodnia (TBL), Zrównoważony wybór dostawcy (SSS), Technika uporządkowania preferencji według podobieństwa do rozwiązania idealnego (TOPSIS), COVID-19

\section{Introduction}

Over a period of time, significant changes have taken place in perceptions of enhancing the social and environmental performance of organizations (Zailani et al., 2012). In the past few periods, due to the rapid natural resource consumption and concerns about the gap between rich and poor and social responsibility, sustainability has become an important practice in professional research. This concern has been demonstrated in legislation to expand organizational responsibilities, while increasing emphasis on the training of sustainable managers and in theories development to support SSCM decisions (Zaid et al., 2018). In SCM, the SSS is the main problem faced by managers in maintaining the strategic competitive position of the organization. From the first purchase of the product to the service provider at the end of its service life, the SSS can be applied to various SSS throughout the product life cycle. As the research literature proves, it is always necessary to consider the tangible and intangible factors of SSS assessment, and the definition of these factors is not always clear (Mani et al., 2018).

Usually, at the time of evaluating SSS the organizations consider cost, delivery, quality, and price, technology, and flexibility criteria. Nowadays, logistics SCM solutions act as significant role in ensuring the competitiveness of the SCM, and the procurement process has become more complicated due to three pillars of sustainability pressures. But now, thanks to many organizations to consider and adoption of a SSCM plan for economic, environmental and social issues and evaluated the sustainability performance of their SSS (Önüt et al., 2009). However, several evaluation models in the literature for SSS. There are many methods for reviewing SSS, such as mixed integer programming, sustainability TBL criteria, weighted linear model method, fuzzy sustainable manufacturing company index (FSMCI), analytic hierarchy process and linear programming model, human judgment model, neural network/case-based reasoning method, statistical analysis, etc. Most of the methods mentioned are based on multiple SSS attributes (Li et al., 2007).

On green SSS number of studies have been carried out. Yeh \& Chuang (2011) studied a large number of papers on how to green principles applicable by environmental principles, which was evaluated by using multi-objective decision analysis. Hung (2011) discusses a fuzzy objective planning method for GSCM optimization based on activity cost accounting and value chain performance evaluation. You, Zhang, Xu, \& Liu, (2020) applied a method of mixed fuzzy multi-criteria decision-making to evaluate the environmental performance of SSS. Govindan, Mina, Esmaeili, \& Gholami-Zanjani, (2020) integrated Hazardous Substance Management (HSM) into GSCM, and proposed a SSS model based on HSM using the ANP method. Liu, Eckert, YannouLe Bris, \& Petit (2019) proposed a fuzzy TOPSIS method to evaluate the environmental performance of SSS. Govindan, Khodaverdi, \& Jafarian, (2013) reviewed a new fuzzy multi-criteria decision-making framework, which is used for SSS with the incomplete information services. More and more authors solve SSS problems based on environmental aspects. The dual focus on environmental and economic standards in SSS must be further expanded to take in social sustainable criteria such as child labour, worker health, and social equity. Though these studies provide insights into the literature on sustainable/green SSS assessments, few people pay attention to SSS assessments that take all sustainability criteria into account. The main contributions of this paper include the SSS decision model in the SSCM based on the concept of TBL. Nicoletti Junior, de Oliveira, $\&$ Helleno (2018) are emphasized that the differences between the economic and social aspects of sustainability and the environmental aspects of sustainability have absorbed such differences.

In view of the past concerns and the multi-criteria nature of SSCM issues, we have proposed a multicriteria framework to assess the sustainability performance of SSS. Multi-criteria decision-making methods (MCDM) in real-world systems usually deal 


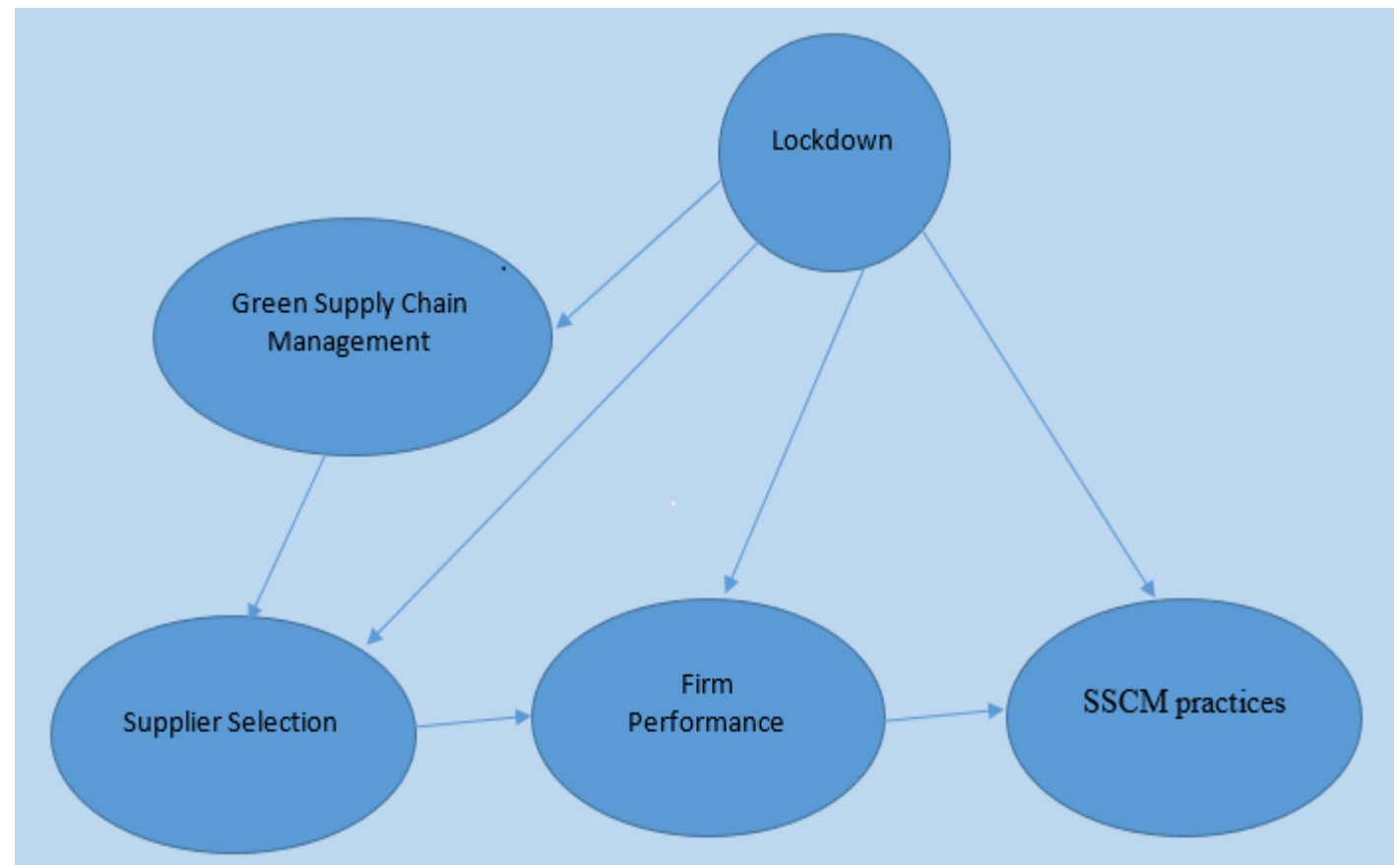

Figure 1. Theoretical framework of the study showing the relationship between green supply chain management, supplier selection, SSCM practices, lockdown, and firm performance

with personal human preferences. Because human judgments and preferences are usually vague and complicated, experts cannot use accurate scale language assessments to estimate their preferences, but can only give accurate language valuations. Therefore, the fuzzy set theory is introduced into the proposed MCDM framework, which aims to resolve such uncertainties (Hashemi et al., 2016). However, the situation of COVID-19 has a negative effect on the companies (Iqbal et al., 2021). COVID-19 affects negatively on all the businesses, which shows a negative impact on firm performance and on SSS. The performance of the supplier is decreased with high speed due to the lockdown. Therefore, the lockdown issue is continuously decreasing the performance of the Firms. Figure 1 shows the relationship between green supply chain management, supplier selection, lockdown, and firm performance.

The structure of this paper is organized as follows: First, principles of SSS by reviewing GSCM, social duty and determining sustainability standards that affect the company's purchasing decisions are reviewed (W. Iqbal et al., 2020). Second, introduce the principles of fuzzy set theory and fuzzy TOPSIS method to evaluate the environmental performance of SSS. Next, introduce the fuzzy TOPSIS and fuzzy set theory to evaluate the environmental performance of SSS. Then, apply and proposed method numerically, to perform sensitivity analysis on the results. Finally, a discussion and some concluding remarks are provided.

\section{Literature Review}

One of the main challenges of sustainable development is to put the definition of the World Commis- sion on Environment and Development into practice and guide decision-making with its terms of reference. Another way to define sustainability is to provide some assistance in the design of human and industrial systems to ensure that use of natural resources and human recycling will not reducing the quality of life due to adverse conditions and the loss of future economic opportunities. The impact of social situations on human health and the atmosphere. This definition clearly shows that concert indicators are required to judge the sustainability and success of any decision (Veleva et al., 2001).

The three pillars of sustainability and SSCM practice include a series of strategies, all of which can make the supply chain more sustainable. Although much work on Green supply chain management (GSCM) has been done in the past, there is very little research on SSCM practices. To meet the needs of various stakeholder groups, increasing market pressure and stricter SSCM practices, organizations have begun to focus on their supply chains. Today, GSCM has become an important concern for companies that incorporate the three pillars of sustainability into their strategy (Rebitzer et al., 2004). The company is aware of the importance of partners taking responsibility for sustainable development in their own expansion, and without SSCM practices, it is impossible to solve the sustainability problems of any organization. (Roy et al., 2020).

The definition of SSCM is to manage the materials and information flow and the cooperation between organizations in the supply chain. As well as it integrates the triple bottom line selection issues including all three pillars of sustainable change (de HaanHoek et al., 2020). The TBL method suggests that in addition to economic performance, organizations 
Table 1. Green supplier selection and evaluation criteria

\begin{tabular}{|c|c|c|c|}
\hline Criteria & Subcriteria & Definition & Source \\
\hline \multirow{4}{*}{$\begin{array}{l}\text { Economic } \\
\text { criteria } \\
\text { (C1) }\end{array}$} & $\begin{array}{l}\text { Product cost, logis- } \\
\text { tics cost }(\mathrm{C} 11)\end{array}$ & $\begin{array}{l}\text { The manufacturing costs that determine the final amount } \\
\text { of the product include maintenance costs, processing costs } \\
\text { and warranty costs. The sum of the unit variable and the } \\
\text { assigned fixed transportation cost. }\end{array}$ & $\begin{array}{l}\text { Hvam, Hansen, Forza, } \\
\text { Mortensen, \& Haug, } \\
\text { 2020, Absi \& Kedad- } \\
\text { sidhoum, } 2003 \text { and } \\
\text { Ghodsypour \& } \\
\text { O’Brien, 2001. }\end{array}$ \\
\hline & $\begin{array}{l}\text { Delivery lead } \\
\text { time(C12) }\end{array}$ & The time between order placement and arrival. & $\begin{array}{l}\text { Chang, Chang, \& Wu, } \\
\text { 2011, } \\
\text { Mafakheri, Breton, \& } \\
\text { Ghoniem, } 2011 .\end{array}$ \\
\hline & $\begin{array}{l}\text { Quality assurance, } \\
\text { Rejection } \\
\text { Ratio (C13) }\end{array}$ & $\begin{array}{l}\text { Obtain quality assurance, such as a certificate. } \\
\text { The number of rejected incoming materials detected } \\
\text { through quality control. }\end{array}$ & $\begin{array}{l}\text { Kannan, Khodaverdi, } \\
\text { Olfat, Jafarian, \& Dia- } \\
\text { bat, 2013, } \\
\text { Ting \& Cho, } 2008 \text {. }\end{array}$ \\
\hline & $\begin{array}{l}\text { Technology } \\
\text { Level of Capabil- } \\
\text { ity } \\
\text { of design, (C14) }\end{array}$ & $\begin{array}{l}\text { The SP technological development can meet the compa- } \\
\text { ny's current and future needs. } \\
\text { The SP new product design capabilities can meet the com- } \\
\text { pany's current and future needs. }\end{array}$ & $\begin{array}{l}\text { Zolfani, Chen, Re- } \\
\text { zaeiniya, \& Tamošai- } \\
\text { tiene, 2012, Gupta \& } \\
\text { Barua, 2017), } \\
\text { Choi \& Hartley, } 1996 .\end{array}$ \\
\hline \multirow{4}{*}{$\begin{array}{l}\text { Environ- } \\
\text { mental cri- } \\
\text { teria }(\mathrm{C} 2)\end{array}$} & $\begin{array}{l}\text { Pollution } \\
\text { production }(\mathrm{C} 21)\end{array}$ & $\begin{array}{l}\text { During the measurement period, the average amount of air } \\
\text { pollutants, wastewater, and solid waste and hazardous } \\
\text { substances discharged per day. }\end{array}$ & $\begin{array}{l}\text { Nielsen, Banaeian, } \\
\text { Golińska, Mobli, \& } \\
\text { Omid, 2014. }\end{array}$ \\
\hline & $\begin{array}{l}\text { Supply } \\
\text { Consumption } \\
(\mathrm{C} 22)\end{array}$ & $\begin{array}{l}\text { The supply and demand relationship in units of raw mate- } \\
\text { rials, water and energy during the measurement period. }\end{array}$ & $\begin{array}{l}\text { Lee, Kang, Hsu, \& } \\
\text { Hung, } 2009 .\end{array}$ \\
\hline & Eco-design(C23) & $\begin{array}{l}\text { Design products to reduce material/energy consumption, } \\
\text { design products for reuse, recycling, material recycling, } \\
\text { design products to avoid or reduce the use of hazardous } \\
\text { materials. }\end{array}$ & $\begin{array}{l}\text { Govindan, Rajendran, } \\
\text { Sarkis \& Murugesan, } \\
\text { 2015, Iqbal, Altalbe, et } \\
\text { al., 2019. }\end{array}$ \\
\hline & $\begin{array}{l}\text { Environmental } \\
\text { management sys- } \\
\text { tem }(\mathrm{C} 24)\end{array}$ & $\begin{array}{l}\text { Environmental certification, such as ISO } 14000 \text {, environ- } \\
\text { mental goal plan, environmental policy, environmental ac- } \\
\text { tivity control and inspection. }\end{array}$ & $\begin{array}{l}\text { Jabbour \& Jabbour, } \\
2009 .\end{array}$ \\
\hline \multirow{4}{*}{$\begin{array}{l}\text { Social Cri- } \\
\text { teria }(\mathrm{C} 3)\end{array}$} & $\begin{array}{l}\text { Employment prac- } \\
\text { tices of internal so- } \\
\text { cial measures(C31) }\end{array}$ & $\begin{array}{l}\text { Discipline and safety regulations, employee contracts, } \\
\text { equal labor resources, diversity, discrimination, flexible } \\
\text { work arrangements, work opportunities, employment com- } \\
\text { pensation, career development. }\end{array}$ & $\begin{array}{l}\text { Bai, Kusi-Sarpong, Ba- } \\
\text { dri Ahmadi, \& Sarkis, } \\
2019 .\end{array}$ \\
\hline & $\begin{array}{lr}\text { Internal } & \text { social } \\
\text { measures } & \text { health } \\
\text { and safety(C32) }\end{array}$ & Health and safety incidents, health and safety practices. & $\begin{array}{l}\text { Luthra, Govindan, } \\
\text { Kannan, Mangla, \& } \\
\text { Garg, 2017. }\end{array}$ \\
\hline & $\begin{array}{l}\text { The impact of ex- } \\
\text { ternal social } \\
\text { measures on local } \\
\text { communities }(\mathrm{C} 33)\end{array}$ & $\begin{array}{l}\text { Health, education, service infrastructure, housing, health } \\
\text { and safety incidents, supervision and public services, sup- } \\
\text { port for educational institutions, safety, cultural property, } \\
\text { economic welfare and growth, social pathology, grants and } \\
\text { donations, and support for community projects. }\end{array}$ & $\begin{array}{l}\text { Azadnia, Saman, \& } \\
\text { Wong, 2015, Irshad et } \\
\text { al., 2019). }\end{array}$ \\
\hline & $\begin{array}{l}\text { The impact of ex- } \\
\text { ternal social } \\
\text { measures on con- } \\
\text { tract stakehold- } \\
\text { ers(C34) }\end{array}$ & $\begin{array}{l}\text { Procurement standards, partnership standards, consumer } \\
\text { education, stakeholder authorization, stakeholder participa- } \\
\text { tion. }\end{array}$ & $\begin{array}{l}\text { Reuter, Goebel, \& } \\
\text { Foerstl, 2012, Iqbal, } \\
\text { Yumei, et al., 2019. }\end{array}$ \\
\hline
\end{tabular}

also need to participate in activities that have a positive impact on SSCM practices and business performance (Khokhar, Iqbal, et al., 2020). By adopting a TBL approach, organizations assume a responsible position with regard to economic, environmental, social prosperity, quality, and justice respectively (Rashidi et al., 2020). 


\subsection{Green Supply Chain Management (GSCM) Se- lection Criteria}

GSCM integrates natural environmental issues into SCM (Parveen et al., 2011). The main goal of GSCM is to remove all wastes inside the industrial development itself, such as water, air and land pollution and property waste, and to reduce hazardous substances. (M. W. Iqbal et al., 2020). The organization that implements a successful GSCM because it considers social criteria in the supply chain environment as well as economic and environmental criteria. Many researchers have used different terms to define a green chain in various ways. Uemura Reche, Canciglieri Junior, Estorilio, \& Rudek (2020) described GSCM defines the procurement and selection of product design materials, from the manufacturing process to the consumer's final product delivery and product life cycle management, and also describes the combination of environmental thinking. The GSCM emphases on how companies use their SSS' process capabilities and technologies to integrate environmental issues, thereby enhancing their competitive advantage (Shahzad et al., 2020).

There are many activities that can be incorporated into GSCM plans and SSCM practices (Ali et al., 2020; Yu et al., 2020). SSS and environmental cooperation includes activities aimed at improving environmental performance and SSS capabilities to carry out joint projects to develop green products and innovation (Qiansong Zhang et al., 2020; Li et al., 2020). SSS in GSCM is clearly a key activity in procurement management, because the company's SSS can prove the company's environmental sustainability and ecological performance (Roehrich et al., 2017). The literature focusing on GSCM aims to obtain certification or introduce green practices through the three pillars of sustainability, so as to promote the SSS and improve SSCM's practices and business preferences (Chiou et al., 2011).

\subsection{Selection criteria for social supply chain man- agement (SCM)}

Organizations are liable for social interests and social interests can also be found in the company's mission and value statement (Diers-Lawson et al., 2020). Although social duty has a long history, the concept of social duty (and sustainability) in the supply chain has only appeared in recent years (OseiKojo et Andrews, 2020). In order to implement the social responsibility system, stakeholders, consumer non-governmental organizations (NGOs) and local community regulations have put increasing pressure on organizations. In the SCM these systems are used to transfer social responsible behaviours, especially those that affect their business partners, and provide benchmarks for environmental principles that society must meet (Shafiq et al., 2020; Mani et al., 2020).

Social duty can be defined as the voluntary combination of environmental and social issues in the or- ganization's business operations and relationships with stakeholders (Qingyu Zhang et al., 2020; Halim Perdana Kusuma et al., 2019). Organizations are increasingly aware that their behavior in procurement and SSCM will greatly regard their status and longstanding success (Baloch et al., 2020). Administrations are responsible for environmental health and safety regulations that promote and protect workers who produce their products, whether they are direct employees or working for SSS (Testa et al., 2020). Social duty has been the subject of many studies. Kelley, Hemphill, \& Thams (2019); Papacharalampous, Papadimitriou, \& Anagnostopoulos (2019) believe that social responsibility includes the economic legal ethics and charity expectations imposed by the society on the organization at a specific time. Teh et al., 2019; Zahid et al. (2020) following categories as important aspects of ethical diversity working conditions at the social level, human rights, security, philanthropy and communities. The practices and difficulties encountered by SMEs in transferring social responsibility behavior to SSS doing business in developing countries but Lockdown has a negative influence on firm performance (Yumei et al., 2021). (Zhang et al., 2019; Morsing, Spence, 2019). The concept of activity focuses on how the organization uses its technology and how to integrate sustainability issues to enhance competitive advantage (Suhi et al., 2019). Oliveira, Leiras, \& Ceryno, (2019); Yazdani, Kahraman, Zarate, \& Onar, (2019) have developed a framework for modelling and analysing complicated universal SCM networks with undertake social obligation through comprehensive risk management and environmental decision-making. Many methods of presenting social

Table 2. Membership functions of linguistic values

\begin{tabular}{|c|c|c|}
\hline Level & Code & Fuzzy numbers \\
\hline Very Low & VL & $(0.1,0.1,0.3)$ \\
\hline Low & L & $(0.1,0.3,0.5)$ \\
\hline Medium & M & $(0.3,0.5,0.7)$ \\
\hline High & H & $(0.5,0.7,0.9)$ \\
\hline Very High & VH & $(0.7,0.9,0.9)$ \\
\hline Very Poor & VP & $(1,1,3)$ \\
\hline Poor & P & $(1,3,5)$ \\
\hline Fair & F & $(3,5,7)$ \\
\hline Good & G & $(5,7,9)$ \\
\hline Very Good & VG & $(7,9,9)$ \\
\hline
\end{tabular}

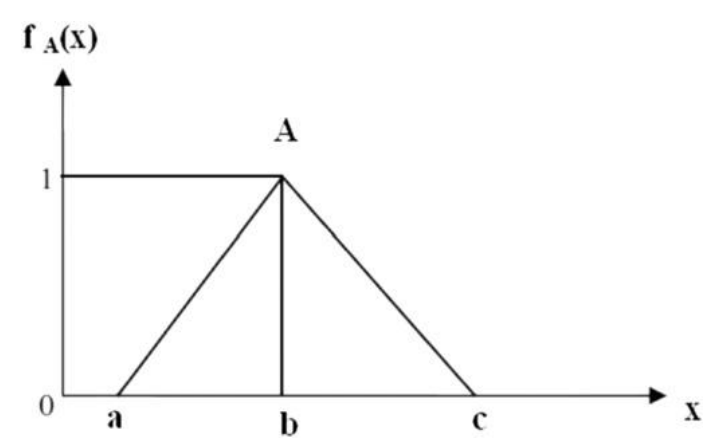

Figure 2. Membership function of triangular fuzzy number A 


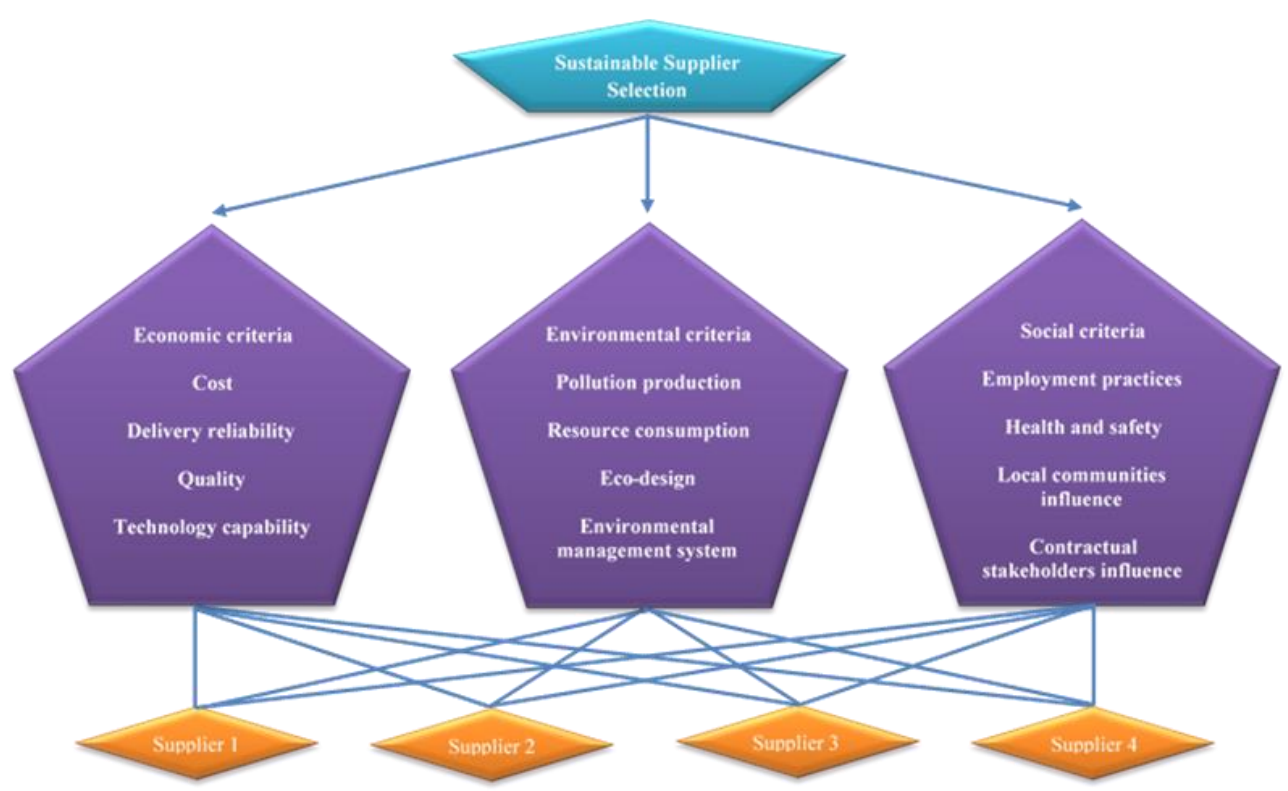

Figure 3. Hierarchical structure of decision problem

Table 3. The importance of the three weighting criteria from Experts

\begin{tabular}{|l|c|c|c|c|c|c|c|c|c|c|c|c|}
\hline \multicolumn{4}{|c|}{ Economic criteria } & \multicolumn{4}{|c|}{ Environmental criteria } & \multicolumn{4}{c|}{ Social criteria } \\
\hline Experts & $\mathrm{C} 11$ & $\mathrm{C} 12$ & $\mathrm{C} 13$ & $\mathrm{C} 14$ & $\mathrm{C} 21$ & $\mathrm{C} 22$ & $\mathrm{C} 23$ & $\mathrm{C} 24$ & $\mathrm{C} 31$ & $\mathrm{C} 32$ & $\mathrm{C} 33$ & $\mathrm{C} 34$ \\
\hline Expert1 & $\mathrm{H}$ & $\mathrm{H}$ & $\mathrm{VH}$ & $\mathrm{M}$ & $\mathrm{VH}$ & $\mathrm{H}$ & $\mathrm{H}$ & $\mathrm{M}$ & $\mathrm{H}$ & $\mathrm{H}$ & $\mathrm{M}$ & $\mathrm{M}$ \\
\hline Expert2 & $\mathrm{VH}$ & $\mathrm{H}$ & $\mathrm{H}$ & $\mathrm{M}$ & $\mathrm{H}$ & $\mathrm{VH}$ & $\mathrm{H}$ & $\mathrm{H}$ & $\mathrm{H}$ & $\mathrm{H}$ & $\mathrm{H}$ & $\mathrm{M}$ \\
\hline Expert3 & $\mathrm{H}$ & $\mathrm{H}$ & $\mathrm{VH}$ & $\mathrm{M}$ & $\mathrm{VH}$ & $\mathrm{H}$ & $\mathrm{H}$ & $\mathrm{M}$ & $\mathrm{VH}$ & $\mathrm{H}$ & $\mathrm{M}$ & $\mathrm{H}$ \\
\hline
\end{tabular}

Table 4. Evaluation of suppliers (SP) on sustainability criteria by Experts

\begin{tabular}{|c|c|c|c|c|c|c|c|c|c|c|c|c|c|}
\hline Experts & \multicolumn{4}{|c|}{ Economic criteria } & \multicolumn{5}{|c|}{ Environmental criteria } & \multicolumn{4}{|c|}{ Social criteria } \\
\hline \multirow{5}{*}{ Expert1 } & Suppliers & $\mathrm{C} 11$ & $\mathrm{C} 12$ & $\mathrm{C} 13$ & $\mathrm{C} 14$ & $\mathrm{C} 21$ & $\mathrm{C} 22$ & $\mathrm{C} 23$ & C24 & C31 & C32 & $\mathrm{C} 33$ & C34 \\
\hline & SP1 & $\mathrm{G}$ & $\mathrm{F}$ & $\mathrm{F}$ & $\mathrm{F}$ & $\mathrm{F}$ & $\mathrm{G}$ & $\mathrm{G}$ & $\mathrm{F}$ & $\mathrm{G}$ & $\mathrm{F}$ & $\mathrm{F}$ & $\mathrm{G}$ \\
\hline & SP2 & $\mathrm{F}$ & $\mathrm{F}$ & $\mathrm{G}$ & $\mathrm{F}$ & $\mathrm{F}$ & $\mathrm{G}$ & $\mathrm{G}$ & VG & $\mathrm{G}$ & $\mathrm{F}$ & $\mathrm{G}$ & $\mathrm{F}$ \\
\hline & SP3 & $\mathrm{VG}$ & $\mathrm{G}$ & $\mathrm{VG}$ & $\mathrm{G}$ & $\mathrm{F}$ & $\mathrm{F}$ & $\mathrm{G}$ & $\mathrm{G}$ & VG & $\mathrm{VG}$ & $\mathrm{G}$ & $\mathrm{F}$ \\
\hline & SP4 & $\mathrm{P}$ & $\mathrm{F}$ & $\mathrm{F}$ & $\mathrm{P}$ & $\mathrm{P}$ & $\mathrm{F}$ & $\mathrm{F}$ & $\mathrm{F}$ & $\mathrm{P}$ & $\mathrm{P}$ & $\mathrm{F}$ & $\mathrm{F}$ \\
\hline \multirow{4}{*}{ Expert2 } & SP1 & $\mathrm{G}$ & $\mathrm{F}$ & $\mathrm{F}$ & $\mathrm{F}$ & $\mathrm{G}$ & $\mathrm{G}$ & $\mathrm{G}$ & $\mathrm{F}$ & $\mathrm{F}$ & VG & $\mathrm{G}$ & G \\
\hline & SP2 & $\mathrm{F}$ & $\mathrm{G}$ & $\mathrm{G}$ & $\mathrm{F}$ & $\mathrm{F}$ & $\mathrm{F}$ & $\mathrm{G}$ & $G$ & $\mathrm{G}$ & $\mathrm{F}$ & $\mathrm{F}$ & $\mathrm{G}$ \\
\hline & SP3 & $\mathrm{G}$ & $\mathrm{G}$ & VG & $\mathrm{F}$ & $\mathrm{G}$ & $\mathrm{G}$ & VG & $\mathrm{F}$ & VG & $\mathrm{F}$ & $\mathrm{G}$ & $\mathrm{G}$ \\
\hline & SP4 & $\mathrm{F}$ & $\mathrm{P}$ & $\mathrm{P}$ & $\mathrm{F}$ & $\mathrm{F}$ & $\mathrm{G}$ & $\mathrm{F}$ & $\mathrm{P}$ & $\mathrm{F}$ & $\mathrm{G}$ & $\mathrm{P}$ & $\mathrm{P}$ \\
\hline \multirow{4}{*}{ Expert3 } & SP1 & $\mathrm{G}$ & $\mathrm{F}$ & $\mathrm{F}$ & $\mathrm{F}$ & $\mathrm{G}$ & $\mathrm{G}$ & $\mathrm{F}$ & VG & VG & $\mathrm{G}$ & $\mathrm{G}$ & $\mathrm{G}$ \\
\hline & SP2 & $\mathrm{F}$ & $\mathrm{F}$ & $\mathrm{G}$ & $\mathrm{G}$ & $\mathrm{G}$ & $\mathrm{G}$ & $\mathrm{F}$ & $\mathrm{F}$ & $\mathrm{F}$ & $\mathrm{P}$ & $\mathrm{F}$ & $\mathrm{G}$ \\
\hline & SP3 & $\mathrm{G}$ & $\mathrm{G}$ & $\mathrm{G}$ & $\mathrm{F}$ & $\mathrm{G}$ & VG & $\mathrm{G}$ & $\mathrm{F}$ & $\mathrm{G}$ & $\mathrm{G}$ & VG & $\mathrm{F}$ \\
\hline & SP4 & $\mathrm{P}$ & $\mathrm{F}$ & $\mathrm{P}$ & $\mathrm{F}$ & $\mathrm{M}$ & $\mathrm{P}$ & $\mathrm{G}$ & $\mathrm{F}$ & $\mathrm{F}$ & $\mathrm{P}$ & $\mathrm{F}$ & $\mathrm{G}$ \\
\hline
\end{tabular}

responsibility and SSCM issues to reverse logistics systems have been studied (Pakistan Bureau of Statistics, 2014; Nikolaou et al., 2013; Sarkis et al., 2010). Figure 2 shows the membership function of triangular fuzzy number A.

\subsection{Sustainable Supplier Selection (SSS) Criteria and Methods}

One of the most important activities to establish SSS decisions is to establish standards system. Since 1960 s, many researchers have focused on the establishment of these criteria. Zafar, Zafar, Sarwar, Raza, $\&$ Khan (2019) were one of the first researchers in this field. The questionnaire papers sent to the administrators of Pakistani companies, he determined 33 different SSS criteria. These standards include product quality, performance assurance, delivery and claims policy production facilities as well as production capacity net prices and technical capabilities. Zafar et al., (2019) concluded that quality delivery and performance history of SSS in Pakistan are the three most important criteria but the role of COVID-19 has remained most harmful to the world economy. The business is decreasing day by day due to the COVID-19 spread. Markets are close, and the revenue of the businesses is declined. In the situation of COVID-19, most of the countries are stopped working and restricted the people to remain inside the houses. Social distancing is one of the major precautions to prevent COVID-19. Therefore, in the organization the SSS and firm performance is also decreased due to the lockdown. However, the supply 
Table 5. Fuzzy set decision matrix and fuzzy weight of criteria

\begin{tabular}{|c|c|c|c|c|c|c|c|c|c|c|c|c|c|c|c|c|c|c|}
\hline $\begin{array}{c}\text { Expert } \\
\text { S }\end{array}$ & $\begin{array}{c}\mathrm{C} 1 \\
1\end{array}$ & & & $\begin{array}{c}\mathrm{C} 1 \\
2\end{array}$ & & & $\begin{array}{c}\mathrm{C} 1 \\
3\end{array}$ & & & $\begin{array}{c}\mathrm{C} 1 \\
4\end{array}$ & & & $\begin{array}{c}\mathrm{C} 2 \\
1\end{array}$ & & & $\begin{array}{c}\mathrm{C} 2 \\
2\end{array}$ & & \\
\hline $\begin{array}{l}\text { We- } \\
\text { ight }\end{array}$ & 0.4 & $\begin{array}{c}0.7 \\
6\end{array}$ & $\begin{array}{c}0 . \\
8\end{array}$ & 0.4 & 0.6 & $\begin{array}{c}0 . \\
8\end{array}$ & 0.4 & $\begin{array}{c}0.7 \\
6\end{array}$ & $\begin{array}{l}0 . \\
8\end{array}$ & 0.2 & 0.4 & $\begin{array}{l}0 . \\
6\end{array}$ & 0.5 & $\begin{array}{c}0.8 \\
2 \\
\end{array}$ & $\begin{array}{l}0 . \\
8 \\
\end{array}$ & 0.4 & $\begin{array}{c}0.7 \\
6 \\
\end{array}$ & $\begin{array}{l}0 . \\
8 \\
\end{array}$ \\
\hline SP1 & 4 & 6 & 8 & 2 & 4 & 6 & 2 & 4 & 6 & 2 & 4 & 6 & 2 & 5.3 & 9 & 5 & 7 & 9 \\
\hline SP2 & 2 & 4 & 6 & 2 & 4.7 & 8 & 4 & 6 & 8 & 2 & 4.7 & 8 & 2 & 4.7 & 8 & 2 & 5.7 & 8 \\
\hline SP3 & 4 & 6.7 & 8 & 4 & 6 & 8 & 6 & 7.3 & 8 & 2 & 4.7 & 8 & 2 & 5.7 & 8 & 2 & 6 & 8 \\
\hline SP4 & 1 & 2.7 & 6 & 1 & 3.3 & 6 & 1 & 2.7 & 6 & 1 & 33 & 6 & 1 & 3.3 & 6 & 1 & 5 & 8 \\
\hline $\begin{array}{c}\text { Expert } \\
\mathrm{S}\end{array}$ & $\begin{array}{c}\mathrm{C} 2 \\
3\end{array}$ & & & $\begin{array}{c}\mathrm{C} 2 \\
4\end{array}$ & & & $\begin{array}{c}\mathrm{C} 3 \\
1\end{array}$ & & & $\begin{array}{c}\mathrm{C} 3 \\
2\end{array}$ & & & $\begin{array}{c}\mathrm{C} 3 \\
3\end{array}$ & & & $\begin{array}{c}\mathrm{C} 3 \\
4\end{array}$ & & \\
\hline $\begin{array}{l}\text { We- } \\
\text { ight }\end{array}$ & 0.4 & 0.6 & $\begin{array}{l}0 . \\
8\end{array}$ & 0.2 & $\begin{array}{c}0.4 \\
7\end{array}$ & $\begin{array}{c}0 . \\
6\end{array}$ & 0.4 & $\begin{array}{c}0.6 \\
6\end{array}$ & $\begin{array}{l}0 . \\
8\end{array}$ & 0.2 & $\begin{array}{c}0.4 \\
7\end{array}$ & $\begin{array}{l}0 . \\
8\end{array}$ & 0.2 & 6.7 & $\begin{array}{l}0 . \\
8\end{array}$ & 0.2 & $\begin{array}{c}0.6 \\
7\end{array}$ & $\begin{array}{l}0 . \\
8\end{array}$ \\
\hline SP1 & 2 & 5.7 & 8 & 2 & 5.7 & 8 & 2 & 6 & 8 & 2 & 6 & 8 & 2 & 6.7 & 8 & 4 & 6 & 8 \\
\hline SP2 & 4 & 6.7 & 8 & 2 & 6 & 8 & 2 & 5.7 & 8 & 1 & 3.3 & 6 & 2 & 4.7 & 8 & 2 & 5.7 & 8 \\
\hline SP3 & 4 & 6.7 & 8 & 2 & 4.7 & 8 & 4 & 7.3 & 8 & 2 & 6 & 8 & 4 & 6.7 & 8 & 2 & 4.7 & 8 \\
\hline SP4 & 2 & 4.7 & 8 & 1 & 3.3 & 6 & 1 & 3.3 & 6 & 1 & 4.7 & 8 & 1 & 3.3 & 6 & 1 & 4 & 8 \\
\hline
\end{tabular}

Table 6. Normalized fuzzy decision matrix

\begin{tabular}{|c|c|c|c|c|c|c|c|c|c|c|c|c|c|c|c|c|c|c|}
\hline Experts & C11 & & & C21 & & & C13 & & & C14 & & & C21 & & & C 22 & & \\
\hline SP1 & 0.1 & 0.13 & 0.1 & 0.32 & 0.55 & 0.77 & 0.32 & 0.55 & 0.77 & 0.32 & 0.55 & 0.77 & 0.32 & 0.6 & 1 & 0.55 & 0.77 & 1 \\
\hline SP2 & 0.13 & 0.1 & 0.32 & 0.32 & 0.62 & 1 & 0.55 & 0.77 & 1 & 0.32 & 0.62 & 1 & 0.32 & 0.62 & 1 & 0.32 & 0.73 & 1 \\
\hline SP3 & 0.1 & 0.12 & 0.1 & 0.55 & 0.77 & 1 & 0.77 & 0.91 & 1 & 0.32 & 0.62 & 1 & 0.32 & 0.73 & 1 & 0.32 & 0.77 & 1 \\
\hline SP4 & 0.13 & 0.26 & 1 & 0.1 & 0.47 & 0.77 & 0.1 & 0.4 & 0.77 & 0.1 & 0.47 & 0.771 & 0.1 & 0.47 & 0.77 & 0.1 & 0.55 & 1 \\
\hline & C23 & & & C24 & & & C 31 & & & C 32 & & & C33 & & & C 34 & & \\
\hline SP1 & 0.32 & 0.73 & 1 & 0.32 & 0.73 & 1 & 0.32 & 0.77 & 1 & 0.32 & 0.77 & 1 & 0.32 & 0.73 & 1 & 0.55 & 0.77 & 1 \\
\hline SP2 & 0.54 & 0.73 & 1 & 0.32 & 0.77 & 1 & 0.32 & 0.73 & 1 & 0.1 & 0.47 & 0.77 & 0.32 & 0.62 & 1 & 0.32 & 0.73 & 1 \\
\hline SP3 & 0.54 & 0.84 & 1 & 0.32 & 0.62 & 1 & 0.55 & 0.91 & 1 & 0.32 & 0.77 & 1 & 0.55 & 0.84 & 1 & 0.32 & 0.62 & 1 \\
\hline SP 4 & 0.32 & 0.62 & 1 & 0.1 & 0.47 & 0.77 & 0.1 & 0.47 & 0.77 & 0.1 & 0.62 & 1 & 0.1 & 0.47 & 0.76 & 0.1 & 0.54 & 1 \\
\hline
\end{tabular}

chain management is still working in lockdown because to manage the supplier selection and green supply chain management is the great importance for survival in the earth. However, it shows a negative role in the performance of the business. As discussed by the previous studies that the business is decreased due to lockdown (Sarkis, 2020). In this situation, the supplier selection and sustainable supply chain management is also facing performance-related issues. Due to the spread of COVID-19, the situation of lockdown is increasing, which causing to decrease in the firm performance (Alkahtani et al., 2021). Ikram, Zhou, Shah, \& Liu (2019) studied that the most important criteria for SSS are product quality, delivery and performance in the past history of Pakistan. Muhammad et al., (2020) proposed the MCDM methods for SSS. Collect and analyse relevant articles that appeared in international journals from 2001 to 2010 to solve the most important criteria considered by experts for SSS. Dweiri, Kumar, Khan, \& Jain (2016) summarized that Since 1960s, many researchers have focused on the establishment of these economic criteria. Figure 3 shows the hierarchical structure of decision problem.

The development of social and green SSS is also essential for effective SSCM, and consideration of environmental and social factors must go beyond the forefront of the organization's SSS agenda but Lockdown has a negative influence on firm performance (Khokhar, Hou, et al., 2020; Ageron et al., 2012). The organization has adopted various methods and activities of SSS decisions is establishing the criteria. In this study, we conclude some criteria that can be applied in the SSS which defined them precisely (Hashemi et al., 2015). The selection criteria are not intended to fully describe the SSS performance, but only as an example of measures that can be formulated. We have summarized many standards and trials that can be measured in the literature in Table 1 from the regard of sustainability.

\section{Fuzzy Numbers}

Natural language expressing awareness or judgment is always personal, unclear or imprecise. The uncertainty and subjectivity of fuzzy numbers have been dealt with by probability and statistics for a long time. Since the accuracy of words is not as good as numbers, the concept of linguistic variables generally describes the definition of events (Chien et al., 2021). The definitions of these events are too poor to be described in predictable quantitative terms. In order to solve the perspicacity of human intelligence, Chou, Chang, \& Shen (2008) introduced fuzzy set theory to precise the linguistic specifications in the process of experts. Fuzzy theory enables experts to deal with the ambiguity involved in data language evaluation. Wang \& Lin (2003) were the first researchers to use fuzzy sets to investigate decisionmaking problems and initiated the FMCDM method. This article uses triangular fuzzy numbers to evaluate experts' preferences (Fu et al., 2021). The purpose for using triangular fuzzy numbers is that experts are instinctively easy to use and calculate.

There are various ways to define fuzzy numbers. A is a real fuzzy number which is described as fuzzy 
subset of the real line $\underline{R}$ with membership function $\mathrm{fA}(\mathrm{x})$, it is a constant mapping from $\mathrm{x}$ in $\mathrm{X}$ to the closed interval $[0,1]$. If the membership level of an element is 1 , it means that the element must be in the set. If the member level is 0 , it means that the element is definitely not in the set. This article defines the perception of fuzzy numbers as follows ( $\mathrm{A}^{-}$et Enginoglu, 2011).

Definition 1. The membership function of the fuzzy number (as show in Fig. 1):

$f_{A}(x)=\left\{\begin{array}{lc}0 & x\langle a ; x\rangle c \\ \frac{x-a}{b-a}, & a \leq x \leq b \\ \frac{c-x}{c-b}, & b \leq x \leq c\end{array}\right.$

Definition 2. Let $A=(a, b, c)$ and $B=\left(a_{1}, b_{1}, c_{1}\right)$ be two triangular fuzzy numbers. Then the operational laws of these two triangular fuzzy numbers are as follows:

$A(+) B=(a, b, c)(+)(a 1, b 1, c 1)=\left(a+a_{1}, b+\right.$

$\left.b_{1}, c+c_{1}\right)$

$A(-) B=(a, b, c)(-)(a 1, b 1, c 1)=\left(a-a_{1}, b-\right.$

$\left.b_{1}, c-c_{1}\right)$

$A\left(^{*}\right) B=(a ; b ; c)\left(^{*}\right)(a 1, b 1, c 1)=$

$\left(a^{*} a_{1}, b^{*} b_{1}, c^{*} c_{1}\right)$

$(A(/) B=(a, b, c)(:)(a 1, b 1, c 1)=(a / a 1, b /$

$\left.\left.b_{1} c / c_{1}\right)\right)$

$K^{*} A=\left(k^{*} a, k^{*} b, k^{*} c\right)$

(A) $-1=(1 / c, 1 / b, 1 / a)$

The distance between A, B fuzzy numbers is calculated as:

$d(A ; B)=$

$\sqrt{1 / 3\left[\left(a-a_{1}\right)^{2}+\left(b-b_{1}\right)^{2}+\left(c-c_{1}\right)^{2}\right]}$

Definition 3. Assume that an expert group has K expert, and the fuzzy rating of each expert $(k=$ $1,2, \ldots, K)$ can be represented as a positive triangular fuzzy number $R_{k}(k=1,2, \ldots, K)$ with membership function $f_{R k}(x)$. Then, the aggregated fuzzy number is defined as:

$R=(a, b, c), k=1,2, \ldots, K$

where

$$
\begin{aligned}
a=\min _{k}\left\{a_{k}\right\}, b & =1 / k \sum_{k}^{k}=1 b_{k}, c \\
& =\max _{k}\left\{c_{k}\right\}
\end{aligned}
$$

\section{The fuzzy TOPSIS method}

The multi-attribute decision-making (MADM) technology functionally related to the problem of discrete alternatives is a practical tool for resolving realworld problems. Since many MADM technologies are involved, (Gati, Krausz, \& Osipow, 1996) provide taxonomies to classify these technologies into information types from experts, prominent information features, and main method categories. Classification does provide us with a clear direction for learning MADM technology (Bernroider et Stix, 2006). In these technologies, since there is a clearly expressed process, the attribute information category from the experts with the information is convenient for decision-making. As in Table 7 and in Figure 4a $\& 4 \mathrm{~b}$ show the weighted normalized fuzzy decision matrix. In this category of TOPSIS, the distance measurement concept as an alternative to the positive ideal solution (PIS) and negative ideal solution (NIS) is the most direct technique in MADM. Table 8 described the distances between suppliers (SP) and A*, A with respect to each criterion.

Meanwhile, this study proposes a related technologies such as ELECTRE and AHP, the characteristics of the TOPSIS method make it a major MADM technology (Kalbar et al., 2012; Kahraman et al., 2007):

$>$ First and for most take unlimited range of all three pillars of sustainability performance attributes and criteria.

$>$ Then clear trade-offs and interactions between performance attributes. More precisely, the change of any one attribute can be compensated by other attributes in an opposite or direct way.

$>$ The MADM technology (such as ELECTRE) method only determines the level of each alternative, and the priority ranking of alternatives with numerical values can better understand the differences and similarities between alternatives(Hou et al, 2019).

$>$ AHP methods circumvents the pair-wise evaluation. This method is used when dealing with a large number of sustainability criteria/sub criteria.

$>$ This is systematic simple calculation process.

$>$ In general simulation comparison, when adding or deleting alternative methods in the MADM method, the rank inversion of TOPSIS is the smallest.

$>\quad$ The TOPSIS solution method includes the following steps (Yue, 2011; Memari et al., 2019; Opricovic,Tzeng, 2004):

Step 1. Compute the normalized decision matrix. The normalized fuzzy-decision matrix can be expressed as:

$R=\left[r_{i j}\right]_{m+n}$

Where $\mathrm{B}$ and $\mathrm{C}$ are the sets of product cost criteria and benefit correspondingly:

$r_{i j}=\left(\frac{a_{i j}}{c_{j}^{*}}, \frac{b_{i j}}{c_{j}^{*}}, \frac{c_{i j}}{c_{j}^{*}}\right), j \in B$

$c_{j}^{*}=\max _{i} c_{i j} j \in B$

$r_{i j}=\left(\frac{a_{j}^{-}}{c_{i j}}, \frac{a_{j}^{-}}{b_{i j}}, \frac{a_{j}^{-}}{a_{i j}}\right), j \in C$

$a_{j}^{-}=\min _{i} a_{i j} j \in C$

The above normalization method aims to retain the standardized attributes of the element $r_{i j}$ (normalized) triangular fuzzy number.

Step 2. Estimate the weighted normalized decision matrix. The weighted normalized value $v_{i j}$ is considered as:

$V=\left[v_{i j}\right]_{m^{*} n} i=1,2, \ldots, m j=1,2, \ldots, n$

Where $v_{i j}=r_{i j}$. $w_{i j}$ and $w_{i j}$ are the weights of the jth attribute, or standard. 
Table 7. Weighted normalized fuzzy decision matrix

\begin{tabular}{|c|c|c|c|c|c|c|c|c|c|c|c|c|c|c|c|c|c|c|}
\hline Experts & C11 & & & $\mathrm{C} 12$ & & & $\mathrm{C} 13$ & & & C14 & & & $\mathrm{C} 21$ & & & $\mathrm{C} 22$ & & \\
\hline SP1 & 0.05 & 0.1 & 0.17 & 0.16 & 0.38 & 0.6 & 0.16 & 0.42 & 0.6 & 0.9 & 0.27 & 0.53 & 0.16 & 0.57 & 0.8 & 0.27 & 0.59 & 0.8 \\
\hline SP2 & 0.006 & 0.14 & 0.2 & 0.16 & 0.43 & 0.8 & 0.27 & 0.59 & 0.8 & 0.9 & 0.31 & 0.6 & 0.16 & 0.61 & 0.8 & 0.16 & 0.56 & 0.8 \\
\hline SP3 & 0.05 & 0.9 & 0.17 & 0.27 & 0.53 & 0.8 & 0.38 & 0.69 & 0.8 & 0.9 & 0.31 & 0.6 & 0.16 & 0.61 & 0.8 & 0.16 & 0.600 .42 & 0.8 \\
\hline \multirow[t]{2}{*}{ SP4 } & 0.06 & 0.2 & 0.8 & 0.05 & 0.32 & 0.6 & 0.05 & 0.31 & 0.6 & 0.02 & 0.23 & 0.53 & 0.05 & 0.39 & 0.6 & 0.005 & 0.42 & \\
\hline & $\mathrm{C} 23$ & & & $\mathrm{C} 24$ & & & C31 & & & C32 & & & C33 & & & C34 & & \\
\hline SP1 & 0.16 & 0.51 & 0.8 & 0.9 & 0.41 & 0.6 & 0.16 & 0.58 & 0.8 & 0.16 & 0.53 & 0.8 & 0.9 & 0.41 & 0.8 & 0.16 & 0.43 & 0.9 \\
\hline SP2 & 0.27 & 0.51 & 0.8 & 0.9 & 0.43 & 0.6 & 0.16 & 0.56 & 0.8 & 0.05 & 0.32 & 0.7 & 0.9 & 0.35 & 0.8 & 0.9 & 0.41 & 0.8 \\
\hline SP3 & 0.27 & 0.59 & 0.8 & 0.9 & 0.35 & 0.6 & 0.28 & 0.69 & 0.8 & 0.16 & 0.53 & 0.8 & 0.16 & 0.48 & 0.8 & 0.9 & 0.35 & 0.9 \\
\hline SP4 & 0.16 & 0.43 & 0.8 & 0.002 & 0.26 & 0.53 & 0.05 & 0.35 & 0.6 & 0.005 & 0.43 & 0.8 & 0.02 & 0.26 & 0.6 & 0.02 & 0.31 & 0.8 \\
\hline
\end{tabular}

Table 8. Distances between suppliers (SP) and A*, A with respect to each criterion

\begin{tabular}{|c|c|c|c|c|c|c|c|c|c|c|c|c|}
\hline & $\mathrm{C} 11$ & $\mathrm{C} 12$ & $\mathrm{C} 13$ & $\mathrm{C} 14$ & $\mathrm{C} 21$ & $\mathrm{C} 22$ & $\mathrm{C} 23$ & $\mathrm{C} 24$ & $\mathrm{C} 31$ & $\mathrm{C} 32$ & $\mathrm{C} 33$ & $\mathrm{C} 34$ \\
\hline $\mathrm{d}\left(\mathrm{SP} 1, \mathrm{~A}^{*}\right)$ & 0.52 & 0.51 & 0.42 & 0.45 & 0.39 & 0.78 & 0.47 & 0.37 & 0.46 & 0.46 & 0.53 & 0.49 \\
\hline $\mathrm{d}\left(\mathrm{SP} 2, \mathrm{~A}^{*}\right)$ & 0.49 & 0.39 & 0.4 & 0.44 & 0.45 & 0.78 & 0.39 & 0.39 & 0.37 & 0.46 & 0.48 & 0.55 \\
\hline $\mathrm{d}\left(\mathrm{SP} 3, \mathrm{~A}^{*}\right)$ & 0.4 & 0.3 & 0.4 & 0.44 & 0.45 & 0.78 & 0.39 & 0.39 & 0.37 & 0.46 & 0.48 & 0.55 \\
\hline $\mathrm{d}\left(\mathrm{SP} 4, \mathrm{~A}^{*}\right)$ & 0.59 & 0.59 & 0.47 & 0.57 & 0.55 & 0.61 & 0.49 & 0.46 & 0.58 & 0.54 & 0.62 & 0.59 \\
\hline $\mathrm{d}\left(\mathrm{SP} 1, \mathrm{~A}^{-}\right)$ & 0.41 & 0.42 & 0.32 & 0.57 & 0.14 & 0.46 & 0.44 & 0.57 & 0.56 & 0.4 & 0.53 & 0.54 \\
\hline $\mathrm{d}\left(\mathrm{SP} 2, \mathrm{~A}^{-}\right)$ & 0.53 & 0.58 & 0.41 & 0.55 & 0.57 & 0.14 & 0.46 & 0.44 & 0.56 & 0.4 & 0.53 & 0.54 \\
\hline $\mathrm{d}\left(\mathrm{SP} 3, \mathrm{~A}^{-}\right)$ & 0.57 & 0.64 & 0.41 & 0.58 & 0.57 & 0.07 & 0.49 & 0.42 & 0.62 & 0.56 & 0.56 & 0.52 \\
\hline $\mathrm{d}\left(\mathrm{SP} 4, \mathrm{~A}^{-}\right)$ & 0.4 & 0.39 & 0.31 & 0.41 & 0.52 & 0.49 & 0.44 & 0.32 & 0.4 & 0.53 & 0.4 & 0.51 \\
\hline
\end{tabular}

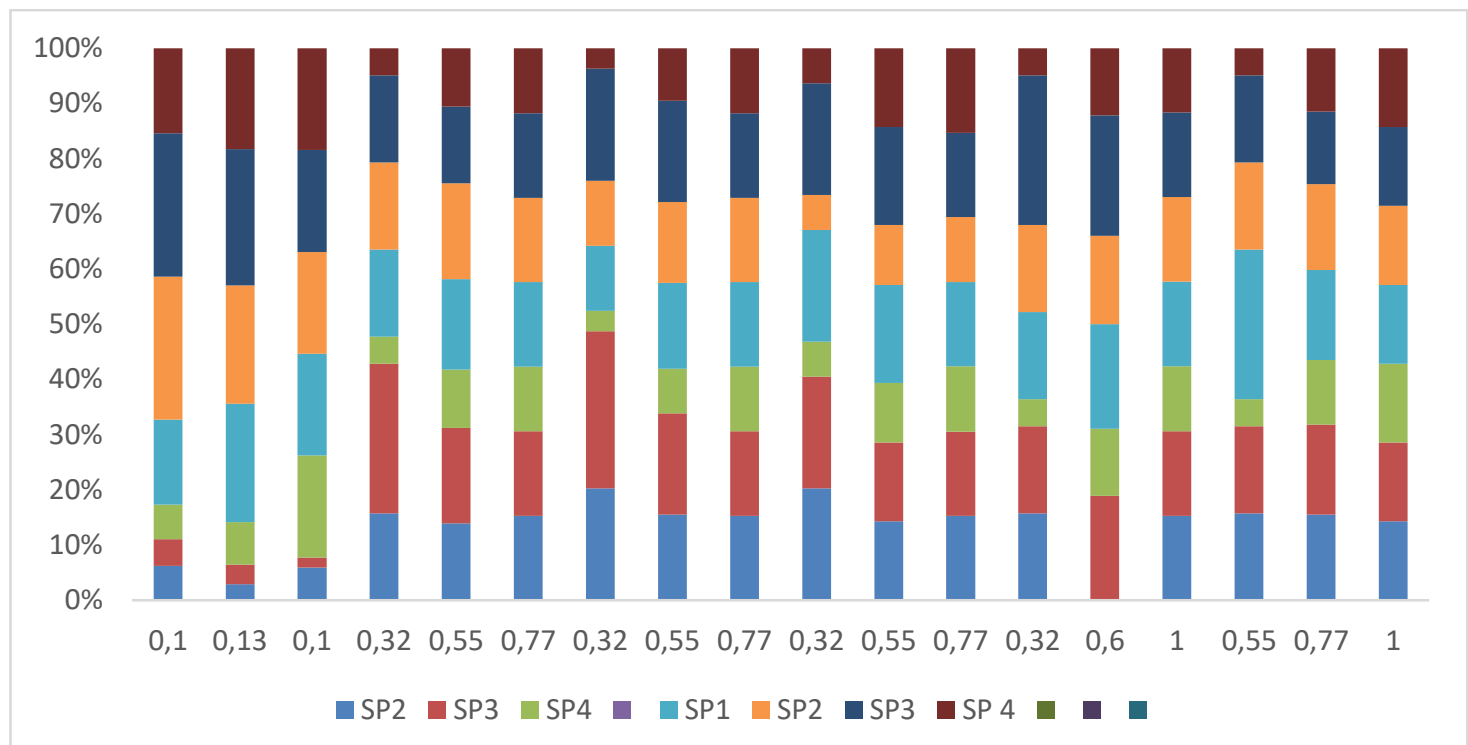

Figure 4a show the weighted normalized fuzzy decision matrix

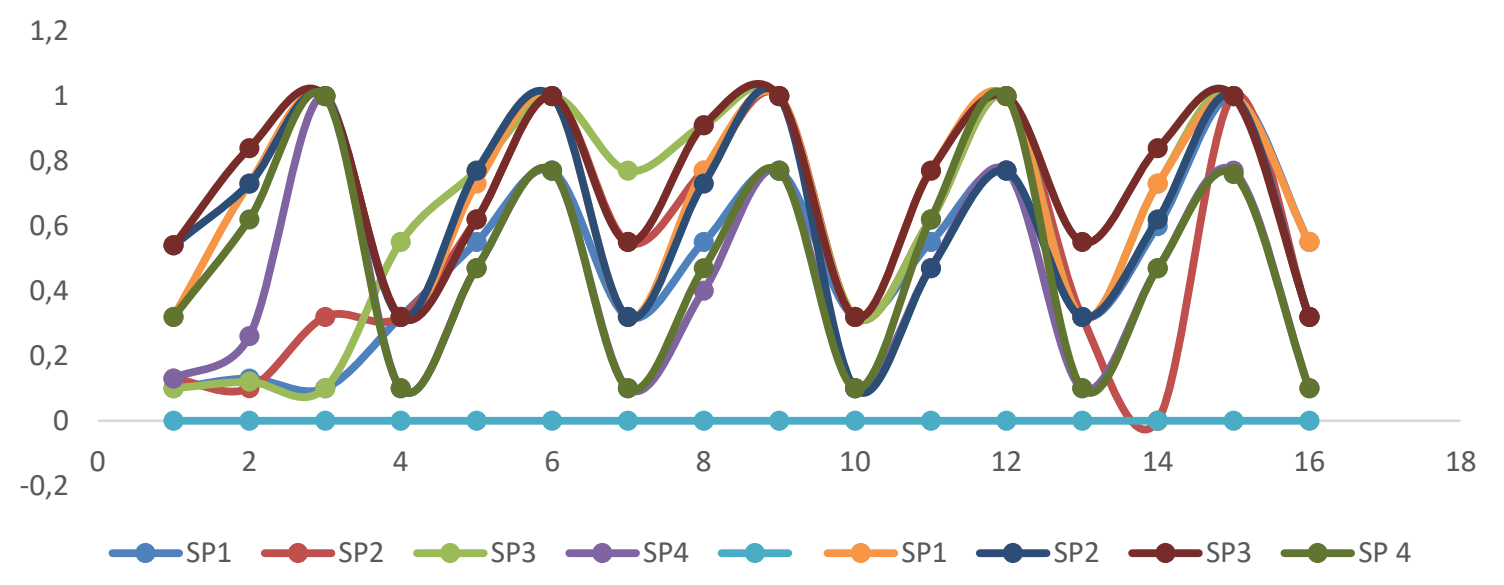

Figure $4 \mathrm{~b}$. show the weighted normalized fuzzy decision matrix 


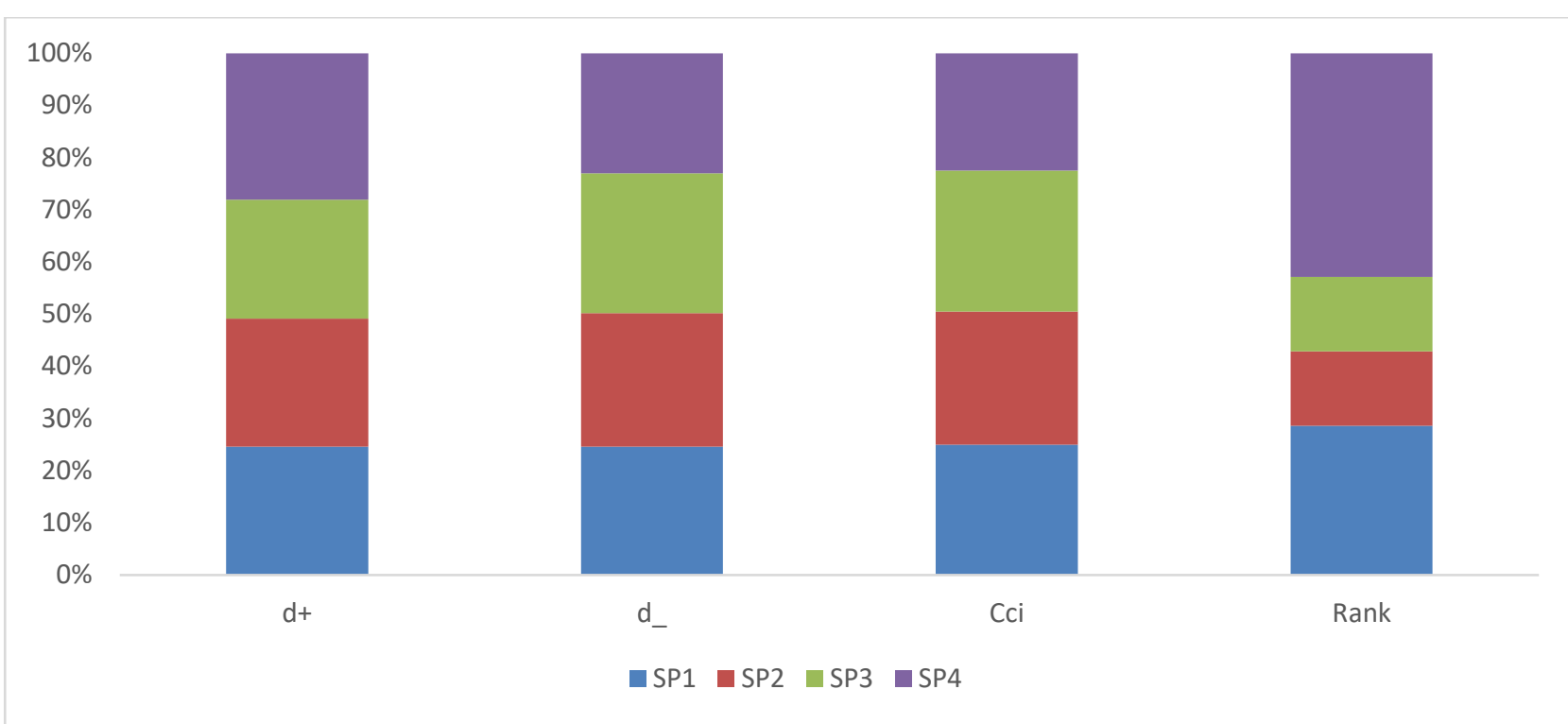

Figure 5. Calculations of d+, d- and cci from the Eq. 15 till Eq. 17

Table 9. Calculations of $\mathrm{d}^{+,} \mathrm{d}^{-}$and cci giving to Eq. 15 till Eq. 17

\begin{tabular}{|c|c|c|c|c|}
\hline & $\mathrm{d}+$ & $\mathrm{d}-$ & Cci & Rank \\
\hline SP1 & 5.94 & 5.61 & 0.485 & 2 \\
\hline SP2 & 5.92 & 5.83 & 0.495 & 1 \\
\hline SP3 & 5.52 & 6.11 & 0.524 & 1 \\
\hline SP4 & 6.77 & 5.23 & 0.435 & 3 \\
\hline
\end{tabular}

Step 3. Determine positive and negative ideal solutions: Fuzzy positive ideal solution (FPIS, $A^{*}$ ) and fuzzy negative ideal of the solution (FNIS, $A^{-}$) can be defined as:

$A^{*}=\left(v_{1}^{*} v_{1}^{*}, \ldots, v_{n}^{*}\right)$

$A^{-}=\left(v_{1}^{-}, v_{2}^{-}, \ldots, v_{n}^{-}\right)$

Where $v_{j}^{*}=\max _{i}\left\{v_{i j 3}\right\}$ and $v_{j}^{-}=\min _{i}\left\{v_{i j 1}\right\}_{;} i=1$;

$2 ; m, j=1,2 ; n$

Step 4. The distance of each alternative from the positive and the negative ideal solution $A^{*}, A^{-}$can be calculated as:

Where $v_{j}^{*}=\max _{i}\left\{v_{j j 3}\right\}$ and $v_{j}^{-}=\min _{\mathrm{i}}\left\{v_{i j 1}\right\}, i=$ $1,2, \ldots, m, j=1,2, \ldots, n$

$d_{i}^{*}=\sum_{j=1}^{n} d_{v}\left(v_{i j}, v_{j}^{*}\right), i=1,2, \ldots, m$

$d_{i}^{-}=\sum_{j=1}^{n} d_{v}\left(v_{i j}, v_{j}^{-}\right), i=1,2, \ldots, m$

and $d_{v}(0,0)$ is the distance measurement among two fuzzy numbers.

Step 5. Estimate the virtual proximity to the ideal resolution. One define the tightness factor to determine all ranking orders possible SP after $d_{i}^{+}$and $d_{i}^{-}$ of each alternative $A_{i}(i=1,2, ., m)$ has been calculated. The closeness coefficient $\left(\mathrm{CC}_{\mathrm{l}}\right)$.The alternative calculation is:

$\mathrm{CC}_{l}=d_{i}^{-} /\left(d_{i}^{+}+d_{i}^{-}\right), i=1,2, \ldots, m$

Step 6. Arrange the order of preferences. Alternative $\mathrm{Ai}$ is closer when cci approaches 1 , FPIS $\left(A^{*}\right)$ moves away from FNIS $\left(A^{-}\right)$. According to the descending order of cci, we can determine sort all alternatives and choose one of the best possible alternatives.

\section{Illustrative Case and Results}

In order to test the practicability of the proposed SSS and evaluation methods, a case of evaluating is illustrated. Fig. 2 shown the hierarchy of the conclusion problem. We present the main criticisms identified in Table 1. Conduct surveys by distributing questionnaires to managers in the areas of business purchase and environment. The assessment consequences determined the comparative significance weights of several standards and grades. As described in Table 1, Figure 3 there are four economic, environmental and social criteria (C11, C12, C13 and C14), (C21, $\mathrm{C} 22, \mathrm{C} 23$ and $\mathrm{C} 24),(\mathrm{C} 31, \mathrm{C} 32, \mathrm{C} 33$ and C34) respectively. $\mathrm{C} 11$ is the product cost criteria. As Figure 6 described the Fuzzy TOPSIS results and sensitivity analysis of sustainable supplier (SP) selection.

Thus currently proposed method is used to solve this problem. Table 2 defines the relative importance weight and rank importance of the criteria described using linguistic variables. The three experts expressed their views on the importance weight of the 12sub-criteria of 3 pillars and the rating of each SSS relative to these criteria/sub-criteria. Table 3 and 4 shows the original evaluation information provided by the three experts. Table 3-5 shows the fuzzy decision matrix and fuzzy weights of the standard normalized fuzzy decision matrix for the distance of each SSS to FPIS and FNIS and the proximity coefficient of each SSS for each criterion, respectively. According to the SSS choice, use Ms Excel to complete all calculations. Figure 7 shows the Sensitivity analysis result. 


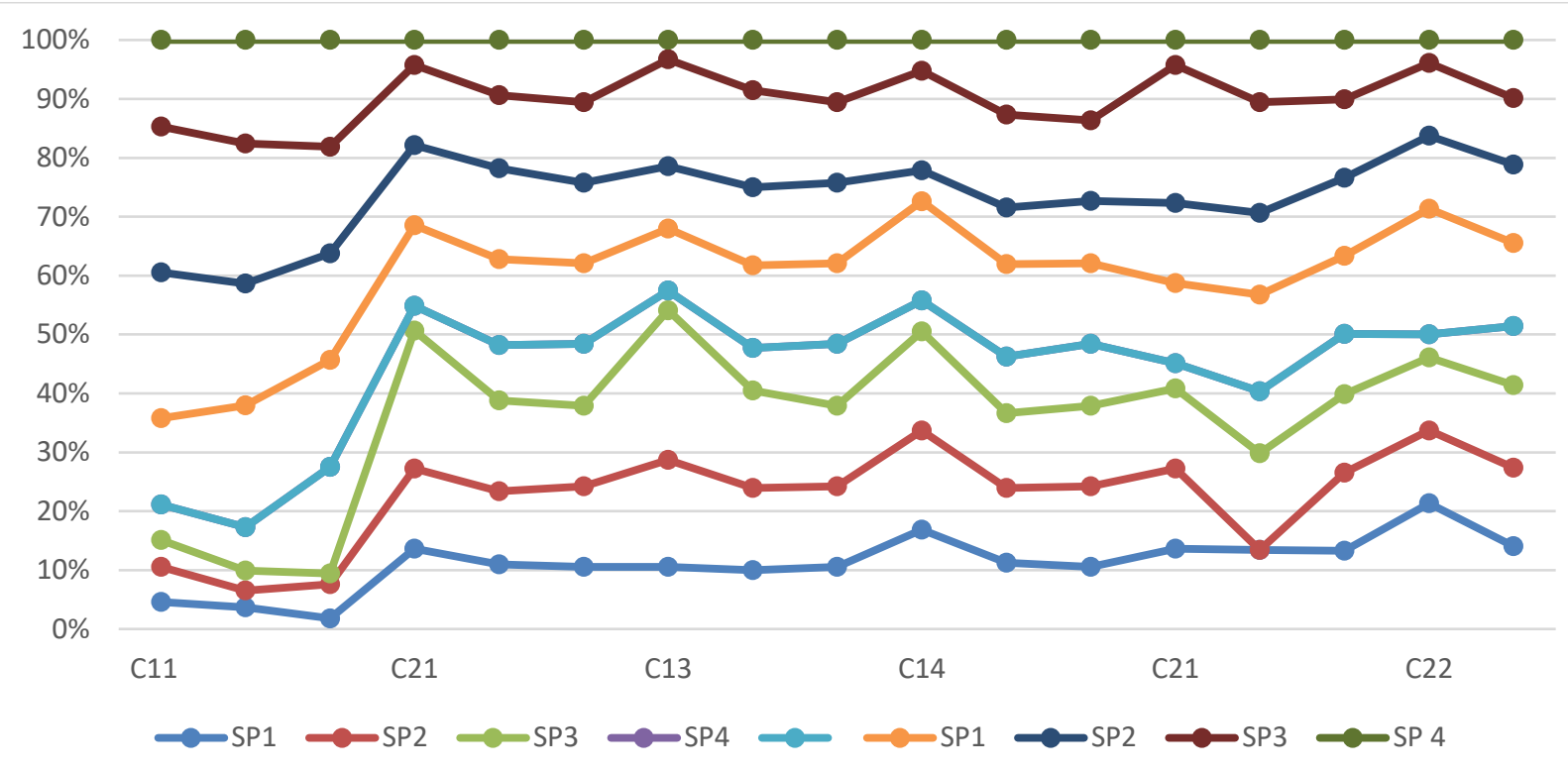

Figure 6. Fuzzy TOPSIS results and sensitivity analysis of sustainable supplier (SP) selection

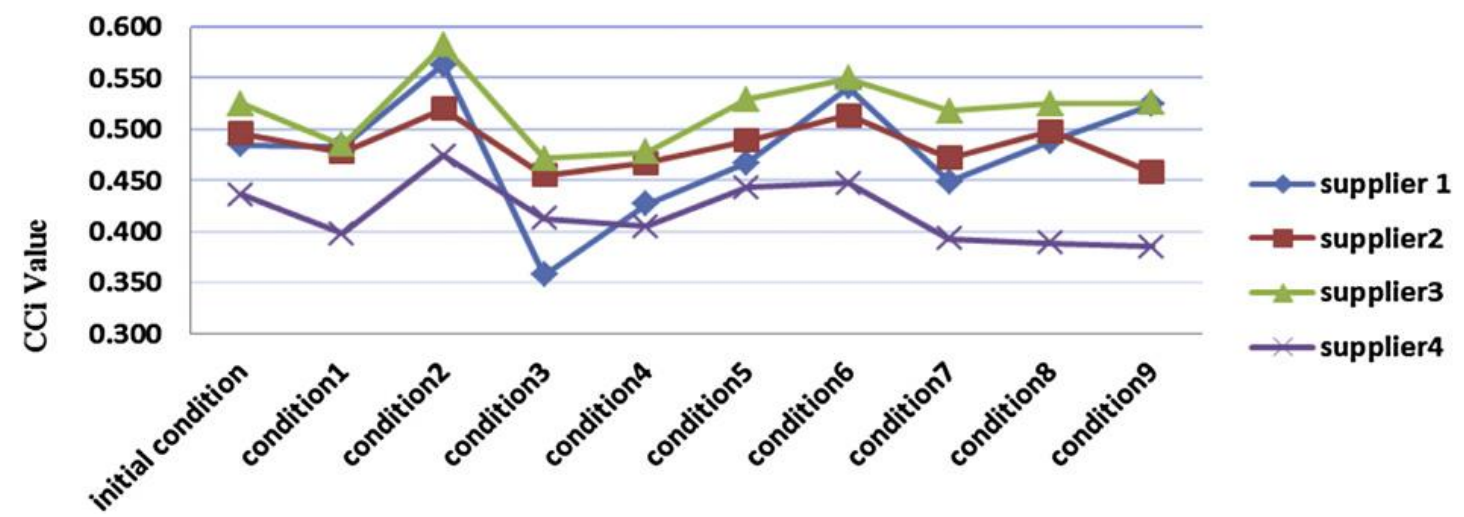

Fig. 7. Sensitivity analysis result

Table 10. Fuzzy TOPSIS method is the result of sensitivity analysis to sustainable supplier (SP) selection

\begin{tabular}{|l|l|l|l|}
\hline Condition & Decision criteria & Experts & $\begin{array}{l}\text { Suppliers (SP) ranking } \\
\text { (Respectively) }\end{array}$ \\
\hline Initial condition & $\begin{array}{l}\text { C11, C12, C13, C14, C21, } \\
\text { C22, C23, C24, C31, C32, } \\
\text { C33, C34 }\end{array}$ & Expert1, Expert2, Expert3 & SP2, SP3, SP4, SP1 \\
\hline Condition1 & C21, C22, C23, C24 & Expert1, Expert2, Expert3 & SP2, SP3, SP4, SP1 \\
\hline Condition2 & C31, C32, C33, C34 & Expert1, Expert2, Expert3 & SP2, SP3, SP4, SP1 \\
\hline Condition3 & C11, C21, C13, C14 & Expert1, Expert2, Expert3 & SP2, SP3, SP4, SP1 \\
\hline Condition4 & C11, C21, C13, C14, C21, & Expert1, Expert2, Expert3 & SP2, SP3, SP4, SP1 \\
& C22, C23, C24 & & \\
\hline Condition5 & C11, C21, C13, C14, C31, & Expert1, Expert2, Expert3 & SP2, SP3, SP4, SP1 \\
\hline Condition6 & C21, C23, C34 & & \\
\hline Condition7 & C32, C33, C34 C24, C31, & Expert1, Expert2, Expert3 & SP2, SP3, SP4, SP1 \\
& C11, C21, C13, C14, C21, & Expert1 & SP2, SP3, SP4, SP1 \\
& C22, C23, C24, C31, C32, & & \\
\hline C33, C34 & C11, C21, C13, C14, C21, & Expert2 & SP2, SP2, SP4, SP1 \\
& C22, C23, C24, C31, C32, & & \\
\hline C33, C34 & C11, C12, C13, C14, C21, & Expert3 & SP2, SP3, SP1, SP1 \\
& C22, C23, C24, C31, C32, & & \\
\hline C33, C34 & & & \\
\hline
\end{tabular}


Table 9 Figure 5 summarizes the final results of fuzzy TOPSIS analysis. According to the value of proximity coefficient $(\mathrm{CCl})$, the rank order of the four SSS according to their sustainability performance is: SSS 2> SSS 3> SSS 4> SSS 1. Therefore, from the perspective of experts, we can achieve that SSS 2 has the best sustainability performance. After considering all sustainability criteria, we have just shown the results of our analysis of SSS. After considering all sustainability criteria, we have just shown the results of our analysis of SSS.

\subsection{Sensitivity analysis}

The purpose of the sensitivity analysis is to deliberate the impact on SSS position when we select altered experts and criteria. This query is useful when there is uncertainty in the definition of the importance of different factors. Table 10 and figure 3 give detailed information on the other nine conditions. According to this sensitivity analysis, changing the fuzzy weight will change the order of SSS. Although the ranking of SSS varies depending on the basis of weights, usually from the all SSS the SSS 2 is the best. Since the decision-making process is a sensitive type of criteria, the expertise should be carefully considered when choosing this process.

\section{Conclusion}

SSCM edges such as SSS, environment and social cooperation can play an important part in accomplishing TBL benefits and promoting sustainable social development. This article emphases on the economic, environmental and social criteria of SSS based on the TBL concept. An inclusive study of sustainable supply chain operations should study all three sustainability features instantaneously. In this article, we introduce a fuzzy MCDM method based on sustainability criteria for SSS decisions. First, determine the criteria for SSS based on the literature. Second, experts implement language scores for standards and alternatives, and then use fuzzy TOPSIS to aggregate scores and generate overall performance scores to measure the SSCM practices and business performance. Finally, we conduct a sensitivity analysis to determine the standard weights by the decision-making process. The results instructed the company to choose the best SSS among the candidates in four ways to continue to cooperate with the SSS team, and suggested that certain SSS improve some defects or stop cooperation with certain SSS. In general, the selection of SSS is one of the most critical factors. This is also based on expert decisions. Through the company's decision-making and implementation, opportunities for improving its sustainability performance can be discovered and prioritized, which can reduce its negative impact of the activity on the environment and society. However, COVID-19 has a negative effect on company performance. Due to the use of COVID-19, countries are under lockdown and business operations seem to be paralyzed. Therefore, the lock-in situation due to COVID-19 has a negative impact on the company's performance.

\section{Limitation}

Though, above discussing article has few limitations. More than 10 SSCM practices have been identified. No other SSCM practices and problems have been discovered, so actual issues regarding the accuracy of these experts' decision-making needs to be investigated to ensure the feasibility of this method. Because, this study conducted in the situation of lockdown, therefore, the companies were not in complete operation that is the reason, there could be weakness in data collection. The situation of COVID-19 is not similar in each country, therefore, future studies should be examined on the other countries to scrutinize the effect green supply chain management, SSCM practices on firm performance. The information and data required to apply this method is one of the limitations of the feasibility of this operation. Supply chain managers should not only adopt this approach, but also maintain such data for future organizational management. Due to the SSS evaluation process, experts face time pressure and lack of expertise on issues related to GSCM and SSCM practices. Although the preferences are not complete, we recommend that you consider SSS. May be this research subject of future research. In addition, various technologies and dynamic evaluation models can be used to integrate the SSS phase with continuous examination. Moreover, the allocation of demand after positioning all SSS is another imperative issue, in future which may become a new trend.

\section{Funding Acknowledgement}

We highly praise the honourable Professor Hou Yumei for her valuable guidance and great support in this research. This research was supported and funded by the project Joint Opyimization of Omni-Channel Retailer Procurement and Pricing Con-sidering Consumer Behavior (G2019203387) un-der the umbrella of Hebei Province Natural Science Foundation Project in 2019.

\section{References}

1. A־ N.C., Enginoglu S., 2011, FP-soft set theory and its applications, Annales of Fuzzy Mathematics and Informatics, 2, http//www.kyungmoon.com.

2. Ageron B., GunaseKaran A., Spalanzani A., 2012, Sustainable supply management: An empirical study, International Journal of Production Economics, 140(1): 168-182,

DOI: 10.1016/j.ijpe.2011.04.007.

3. Ali Y., SaAd Bin T., Sabir M., Muhammad N., SAlman A., ZEB K., 2020, Integration of green supply chain management practices in construction supply chain of CPEC, Management of Environmental Quality: An International Journal, 31(1): 185-200, DOI: 10.1108/MEQ-12-2018-0211. 
4. Alkahtani M., OMair M., Khalid Q.S., Hussain G., Ahmad I., Pruncu C., 2021, A COVID-19 Supply Chain Management Strategy Based on Variable Production under Uncertain Environment Conditions, International Journal of Environmental Research and Public Health, 18(4): 1662,

DOI: $10.3390 /$ ijerph18041662.

5. Baloch Z.A., TAN Q., IQBal N., Mohsin M., ABbaS Q., IQBal W., Chaudhry I.S., 2020, Trilemma assessment of energy intensity, efficiency, and environmental index: evidence from BRICS countries, Environmental Science and Pollution Research, 27(27): 34337-34347,

DOI: $10.1007 / \mathrm{s} 11356-020-09578-3$.

6. Bernroider E.W.N., Stix V., 2006, Profile distance method-a multi-attribute decision making approach for information system investments, Decision Support Systems, 42(2): 988-998,

DOI: $10.1016 /$ j.dss.2005.02.006

7. Chien F.S., Kamran H.W., Albashar G., Igbal W., 2021, Dynamic planning, conversion, and management strategy of different renewable energy sources: A Sustainable Solution for Severe Energy Crises in Emerging Economies, International Journal of Hydrogen Energy, 46(11): 7745-7758, DOI: 10.1016/j.ijhydene.2020.12.004.

8. Chiou T.Y., Chan H.K., Lettice F., Chung S.H., 2011, The influence of greening the suppliers and green innovation on environmental performance and competitive advantage in Taiwan. Transportation Research Part E: Logistics and Transportation Review, 47(6): 822-836,

DOI: 10.1016/j.tre.2011.05.016.

9. Chou S.Y., Chang Y.H., Shen C.Y., 2008, A fuzzy simple additive weighting system under group decision-making for facility location selection with objective/subjective attributes, European Journal of Operational Research, 189(1): 132-145, DOI: 10.1016/j.ejor.2007.05.006.

10. de HaAn-Hoek J., Lambrechts W., Semeijn J., CANIËLS M.C.J., 2020, Levers of Control for Supply Chain Sustainability: Control and Governance Mechanisms in a Cross-Boundary Setting. Sustainability, 12(8): 3189,

DOI: $10.3390 /$ su12083189.

11. Diers-Lawson A., Coope K., Tench R., 2020, Why can CSR seem like putting lipstick on a pig? Evaluating CSR authenticity by comparing practitioner and consumer perspectives, Journal of Global Responsibility (ahead-of-print), DOI: 10.1108/jgr-02-2020-0033.

12. Dweiri F., Kumar S., Khan S. A., Jain V., 2016, Designing an integrated AHP based decision support system for supplier selection in automotive industry, Expert Systems with Applications, 62: 273-283, DOI: 10.1016/j.eswa.2016.06.030.

13. Fu F.Y., Alharthi M., Bhatti Z., Sun L., Rasul F., HANIF I., IQBAL W., 2021, The dynamic role of energy security, energy equity and environmental sustainability in the dilemma of emission reduction and economic growth, Journal of Environmental Management, 280: 111828, DOI: $10.1016 /$ j.jenvman.2020.111828.

14. Gati I., Krausz M., OsIPOW S.H., 1996, A Taxonomy of Difficulties in Career Decision Making, Journal of Counseling Psychology, 43(4): 510-526, DOI: 10.1037/0022-0167.43.4.510.
15. Govindan K., KhOdAVERdi R., JafARian A., 2013, A fuzzy multi criteria approach for measuring sustainability performance of a supplier based on triple bottom line approach. Journal of Cleaner Production, 47: 345-354,

DOI: 10.1016/j.jclepro.2012.04.014.

16. Govindan K., Mina H., Esmaeili A., GholamiZANJANI S.M., 2020, An Integrated Hybrid Approach for Circular supplier selection and Closed loop Supply Chain Network Design under Uncertainty, Journal of Cleaner Production, 242, DOI: $10.1016 /$ j.jclepro.2019.118317.

17. Halim P.K.A., Muslim M., Murdifin I., Faisal P.M.A., Halim P.K.P.A., MuARa A.A., Halim J.M., 2019, Environmental Disclosure as Corporate Social Responsibility: Evidence from the Biggest Nickel Mining in Indonesia International Journal of Energy Economics and Policy Environmental Disclosure as Corporate Social Responsibility: Evidence from the Biggest Nickel Mining in Indonesia, International Journal of Energy Economics and Policy, 9, DOI: 10.32479/ijeep.7048.

18. Hashemi S.H., Karimi A., Tavana M., 2015, An integrated green supplier selection approach with analytic network process and improved Grey relational analysis, International Journal of Production Economics, 159: 178-191, DOI: 10.1016/j.ijpe.2014.09.027.

19. Hashemi S.S., Hajiagha S.H.R., Zavadskas E.K., MAHDIRAJI H.A., 2016, Multicriteria group decision making with ELECTRE III method based on intervalvalued intuitionistic fuzzy information, Applied Mathematical Modelling, 40(2): 1554-1564, DOI: 10.1016/j.apm.2015.08.011.

20. Hou Y., Iqbal W., Muhammad S.G., Iqbal N., Ahmad S.Y., Fatima A., 2019, Measuring Energy Efficiency and Environmental Performance: A Case of South Asia, Processes, 7(6): 325, DOI: $10.3390 /$ pr7060325.

21. Hou Y., Khokhar M., Khan M., Islam T.,Haider I., 2021, Put Safety First: Exploring the Role of Health and Safety Practices in Improving the Performance of SMEs, Sage Open, 11(3), DOI: $10.1177 / 21582440211032173$.

22. HunG S.J., 2011, Activity-based divergent supply chain planning for competitive advantage in the risky global environment: A DEMATEL-ANP fuzzy goal programming approach, Expert Systems with Applications, 38(8): 9053-9062,

DOI: 10.1016/j.eswa.2010.09.024.

23. IKrAm M., ZhOu P., SHAh S A A., Liu G.Q., 2019, Do environmental management systems help improve corporate sustainable development? Evidence from manufacturing companies in Pakistan. Journal of Cleaner Production, 226: 628-641, DOI: 10.1016/J.JCLEPRO.2019.03.265.

24. IQbal M.W., KANG Y., JeON H.W., 2020, Zero waste strategy for green supply chain management with minimization of energy consumption, Journal of Cleaner Production, 245: 118827 , DOI: $10.1016 /$ j.jclepro.2019.118827.

25. Iqbal S., Bilal A.R., Nurunnabi M., Iqbal W., ALFAKHRI Y., IQBAL N., 2021, It is time to control the worst: testing COVID-19 outbreak, energy consumption and $\mathrm{CO}_{2}$ emission, Environmental Science and Pollution Research, 28(15): 1900819020, DOI: 10.1007/s11356-020-11462-z. 
26. IQbal W., Altalbe A., Fatima A., Ali A., Hou Y., 2019, A DEA Approach for Assessing the Energy, Environmental and Economic Performance of Top 20 Industrial Countries, Processes, 7(12): 902, DOI: $10.3390 / p r 7120902$.

27. Iqbal W., Fatima A., Yumei H., Abbas Q., Iram R., 2020, Oil supply risk and affecting parameters associated with oil supplementation and disruption, Journal of Cleaner Production, 255: 120187, DOI: $10.1016 /$ j.jclepro.2020.120187.

28. Iqbal W., Yumei H., Abbas Q., Hafeez M., Mohsin M., Fatima A., Sohail N., 2019, Assessment of Wind Energy Potential for the Production of Renewable Hydrogen in Sindh Province of Pakistan. Processes, 7(4): 196, DOI: 10.3390/pr7040196.

29. Irshad L., Arshad S.M., Khokhar M., 2019, A Novel Localization Technique Using Luminous Flux, Applied Sciences, 9(23): 5027, DOI: $10.3390 / a p p 9235027$.

30. Kahraman C., Yasin A.N., Çevik S., Gülbay M., AYÇA E.S., 2007, Hierarchical fuzzy TOPSIS model for selection among logistics information technologies, Journal of Enterprise Information Management, 20(2): 143-168, DOI: 10.1108/17410390710725742.

31. Kalbar P.P., Karmakar S., AsoleKar S.R., 2012, Selection of an appropriate wastewater treatment technology: A scenario-based multiple-attribute decision-making approach, Journal of Environmental Management, 113: 158-169,

DOI: $10.1016 /$ j.jenvman.2012.08.025.

32. Kelley K.J., Hemphill T.A., Thams Y., 2019, Corporate social responsibility, country reputation and corporate reputation: A perspective on the creation of shared value in emerging markets, Multinational Business Review, 27(2): 178-197, DOI: 10.1108/MBR-07-2017-0047.

33. Кнокнав M., 2019, Occupational Health Safety Implemntation Framework for Pakistani Construction Industry, 3C Tecnología. Glosas de innovación aplicadas a la pyme, 253-285.

34. Khokhar M., Hou Y., Rafique M.A., IQbal W., 2020, Evaluating the Social Sustainability Criteria of Supply Chain Management in Manufacturing Industries: A Role of BWM in MCDM, Problemy Ekorozwoju/ Problems of Sustainable Development, 15(2)2020: 185-194.

35. Khokhar M., Iqbal W., Hou Y., Abbas M., Fatima A., 2020, Assessing Supply Chain Performance from the Perspective of Pakistan's Manufacturing Industry Through Social Sustainability, Processes, 8(9): 1064, DOI: 10.3390/pr8091064.

36. Li G.D., Yamaguchi D., Nagai M., 2007, A greybased decision-making approach to the supplier selection problem, Mathematical and Computer Modelling, 46(3-4): 573-581, DOI: j.mcm.2006.11.021.

37. Li S., QiaO J., Cui H., WANG S., 2020, Realizing the Environmental Benefits of Proactive Environmental Strategy: The Roles of Green Supply Chain Integration and Relational Capability, Sustainability, 12(7): 2907, DOI: 10.3390/su12072907.

38. Liu Y., Eckert C., Yannou-Le Bris G., Petit G., 2019, A fuzzy decision tool to evaluate the sustainable performance of suppliers in an agrifood value chain, Computers and Industrial Engineering, 127: 196-212, DOI: 10.1016/j.cie.2018.12.022.
39. Mani V., Gunasekaran A., Delgado C., 2018, International Journal of Production Economics Supply chain social sustainability : Standard adoption practices in Portuguese manufacturing firms, International Journal of Production Economics, 198: 149-164, DOI: 10.1016/j.ijpe.2018.01.032.

40. Mani V., Jabbour C.J.C., Mani K.T.N., 2020, Supply chain social sustainability in small and medium manufacturing enterprises and firms' performance: Empirical evidence from an emerging Asian economy, International Journal of Production Economics, 227: 107656, DOI: 10.1016/j.ijpe.2020.107656.

41. Memari A., Dargi A., Akbari J.M.R., Ahmad R., ABDUL R., 2019, Sustainable supplier selection: A multi-criteria intuitionistic fuzzy TOPSIS method, Journal of Manufacturing Systems, 50: 9-24, DOI: $10.1016 /$ j.jmsy.2018.11.002.

42. Morsing M., SPence L.J., 2019, Corporate social responsibility (CSR) communication and small and medium sized enterprises: The governmentality dilemma of explicit and implicit CSR communication. Human Relations, 72(12): 19201947, DOI: 10.1177/0018726718804306.

43. Muhammad N., Fang Z., Shah S.A.A., AKbar M.A., Alsanad A., Gumaei A., Solangi Y.A., 2020, A Hybrid Multi-Criteria Approach for Evaluation and Selection of Sustainable Suppliers in the Avionics Industry of Pakistan, Sustainability, 12(11): 4744, DOI: $10.3390 /$ su12114744.

44. Nicoletti Junior A., De Oliveira M.C., Helleno A.L., 2018, Sustainability evaluation model for manufacturing systems based on the correlation between triple bottom line dimensions and balanced scorecard perspectives, Journal of Cleaner Production, 190: 84-93, DOI: 10.1016/j.jclepro.2018.04.136.

45. Nikolaou I. E., Evangelinos K. I., Allan S., 2013, A reverse logistics social responsibility evaluation framework based on the triple bottom line approach, Journal of Cleaner Production, 56: 173-184, DOI: 10.1016/j.jclepro.2011.12.009.

46. Oliveira, F.N. De, Leiras A., Ceryno P., 2019, Environmental risk management in supply chains: A taxonomy, a framework and future research avenues, Journal of Cleaner Production, DOI: 10.1016/j.jclepro.2019.06.032.

47. ÖNÜT S., KARA S.S., IșIK E., 2009, Long term supplier selection using a combined fuzzy MCDM approach: A case study for a telecommunication company, Expert Systems with Applications, 36(2 PART 2): 3887-3895, DOI: 10.1016/j.eswa.2008.02.045.

48. Opricovic S., Tzeng G.H., 2004, Compromise solution by MCDM methods: A comparative analysis of VIKOR and TOPSIS, European Journal of Operational Research, 156(2): 445-455, DOI: $10.1016 / \mathrm{S} 0377-2217(03) 00020-1$.

49. Osei-Kojo A., ANDREws N., 2020, A developmental paradox? The 'dark forces' against corporate social responsibility in Ghana's extractive industry, Environment, Development and Sustainability, 22(2): 1051-1071, DOI: 10.1007/s10668-018-0233-9.

50. Pakistan Bureau of Statistics, 2014, Pakistan Employment Trends, 1-32.

51. Papacharalampous N., PAPAdimitriou D., AnAGNOSTOPOUlos C., 2019, 'Walking the talk' in times of recession: the case of corporate social 
responsibility in Greece, Journal of Global Responsibility, 10(2): 102-118,

DOI: 10.1108/jgr-11-2018-0058.

52. PARVEEN C.M., KuMAR A.R.P., NARASIMHA R.T.V.V. L., 2011, Integration of lean and green supply chain - Impact on manufacturing firms in improving environmental efficiencies, Proceedings of the International Conference on Green Technology and Environmental Conservation, GTEC-2011: 143147, DOI: 10.1109/GTEC.2011.6167659.

53. RASHIDI K., NOORIZADEH A., KANNAN D., Cullinane K., 2020, Applying the triple bottom line in sustainable supplier selection: A meta-review of the state-of-the-art, Journal of Cleaner Production, 269: 122001, DOI: 10.1016/j.jclepro.2020.122001.

54. Rebitzer G., Ekvall T., FrischKNeCht R., Hunkeler D., Norris G., RYdBerg T., PENNINGTON D.W., 2004, Life cycle assessment Part 1: Framework, goal and scope definition, inventory analysis, and applications, Environment International, DOI: 10.1016/j.envint.2003.11.005.

55. Roehrich J.K., Hoejmose S.U., Overland V., 2017, Driving green supply chain management performance through supplier selection and value internalisation: A self-determination theory perspective, International Journal of Operations and Production Management, 37(4): 489-509, DOI: 10.1108/IJOPM-09-2015-0566.

56. ROY V., SCHOENHERR T., CHARAN P., 2020, Toward an organizational understanding of the transformation needed for sustainable supply chain management: The concepts of force-field and differential efforts, Journal of Purchasing and Supply Management, 26(3): 100612, DOI: j.pursup.2020.100612.

57. SARKIS J., 2020, Supply chain sustainability: learning from the COVID-19 pandemic, International Journal of Operations and Production Management, 41(1): 63-73, DOI: 10.1108/IJOPM-08-2020-0568.

58. Sarkis J., Helms M.M., Hervani A.A., 2010, Reverse logistics and social sustainability, Corporate Social Responsibility and Environmental Management, 17(6): 337-354, DOI: 10.1002/csr.220.

59. ShafiQ A., Ahmed M.U., Mahmoodi F., 2020, Impact of supply chain analytics and customer pressure for ethical conduct on socially responsible practices and performance: An exploratory study, International Journal of Production Economics, 225: 107571, DOI: 10.1016/j.ijpe.2019.107571.

60. Shahzad F., Du J., Khan I., Shahbaz M., Murad M., 2020, Untangling the influence of organizational compatibility on green supply chain management efforts to boost organizational performance through information technology capabilities, Journal of Cleaner Production, 266: 122029, DOI: 10.1016/j.jclepro.2020.122029.

61. Suhi S.A., Enayet R., Haque T., Ali S.M., MoKTAdir M.A., Paul S.K., 2019, Environmental sustainability assessment in supply chain: An emerging economy context, Environmental Impact Assessment Review, 79: 106306, DOI: 10.1016/j.eiar.2019.106306.

62. Teh L.C.L., CAdDell R., Allison E.H., Finkbeiner E. M., KitTinger J.N., NAKAMURA K., OtA Y., 2019, The role of human rights in implementing socially responsible seafood, PLOS ONE, 14(1): e0210241, DOI: 10.1371/journal.pone.0210241.
63. Testa F., Corsini F., Gusmerotti N.M., Iraldo F., 2020, Predictors of organizational citizenship behavior in relation to environmental and health \& safety issues, International Journal of Human Resource Management, 31(13): 1705-1738, DOI: 10.1080/09585192.2017.1423099.

64. Uemura R.A.Y., CANCIGLIERI Junior O., Estorilio C.C. A., RUDEK M., 2020, Integrated product development process and green supply chain management: Contributions, limitations and applications. Journal of Cleaner Production, 249: 119429, DOI: 10.1016/j.jclepro.2019.119429.

65. Veleva V., Hart M., Greiner T., Crumbley C., 2001, Indicators of sustainable production, Journal of Cleaner Production, 9(5): 447-452, DOI: 10.1016/S0959-6526(01)00004-X.

66. WANG J., LiN Y.I., 2003, A fuzzy multicriteria group decision making approach to select configuration items for software development, Fuzzy Sets and Systems, 134(3): 343-363, DOI: 10.1016/S0165-0114(02)00283-X.

67. Yazdani M., Kahraman C., Zarate P., Onar S.C., 2019, A fuzzy multi attribute decision framework with integration of QFD and grey relational analysis, Expert Systems with Applications, 115: 474-485, DOI: 10.1016/j.eswa.2018.08.017.

68. Yeh W.C., Chuang M.C., 2011, Using multiobjective genetic algorithm for partner selection in green supply chain problems, Expert Systems with Applications, 38(4): 4244-4253,

DOI: 10.1016/j.eswa.2010.09.091.

69. You S.-Y., Zhang L.-J., Xu X.-G., LiU H.-C., 2020, A New Integrated Multi-Criteria Decision Making and Multi-Objective Programming Model for Sustainable Supplier Selection and Order Allocation, Symmetry, 12(2): 302, DOI: 10.3390/sym12020302.

70. Yu W., Chavez R., Feng M., Wong C.Y., Fynes B., 2020, Green human resource management and environmental cooperation: An ability-motivationopportunity and contingency perspective, International Journal of Production Economics, 219: 224-235, DOI: 10.1016/j.ijpe.2019.06.013.

71. YuE Z., 2011, A method for group decision-making based on determining weights of decision makers using TOPSIS, Applied Mathematical Modelling, 35(4): 1926-1936, DOI: 10.1016/j.apm.2010.11.001.

72. Yumei H., Iqbal W., Nurunnabi M., Abbas M., Jingde W., Chaudhry I.S., 2021, Nexus between corporate social responsibility and firm's perceived performance: evidence from SME sector of developing economies, Environmental Science and Pollution Research, 28(2): 2132-2145, DOI: $10.1007 / \mathrm{s} 11356-020-10415-w$.

73. YuMEI H.J.W.Q.G.Y.W.M.K.J.L., 2020, Considering the Patient Satisfaction and Staffing skill the Optimization of Surgical Scheduling by Particle Swarm and Genetic Algorithm, Solid State Technology: 2096-2111, http://www.solidstatetechno logy.us/index.php/JSST/article/view/4809.

74. Zafar A., Zafar M., SARwar A., Raza H., Khan M.T., Zafar A., Zafar M., Sarwar A., Raza H., Khan M.T. (2019) A Fuzzy AHP Method for Green Supplier Selection and Evaluation, Proceedings of the Twelfth International Conference on Management Science and Engineering Management, eds. Xu J., Cooke F., Gen M., Ahmed S., Springer, Cham, DOI: 10.1007/978-3-319-93351-1_105. 
75. Zahid M., Rahman H.U., Ali W., Khan M., AlHARTHI M., IMRAN QURESHI M., JAN A., 2020, Boardroom gender diversity: Implications for corporate sustainability disclosures in Malaysia, Journal of Cleaner Production, 244: 118683, DOI: 10.1016/j.jclepro.2019.118683.

76. ZAID A.A., JAARON A.A.M., TALIB B.A., 2018, The impact of green human resource management and green supply chain management practices on sustainable performance: An empirical study, Journal of Cleaner Production, 204: 965-979, DOI: 10.1016/J.JCLEPRO.2018.09.062.

77. Zailani S., Jeyaraman K., Vengadasan G., PremkUmar R., 2012, Sustainable supply chain management (SSCM) in Malaysia: A survey, International Journal of Production Economics, 140(1):, 330-340, DOI: 10.1016/j.ijpe.2012.02.008.
78. ZHANG Q., Oo B.L., LiM B.T.H., 2019, Drivers, motivations, and barriers to the implementation of corporate social responsibility practices by construction enterprises: A review, Journal of Cleaner Production, DOI: 10.1016/j.jclepro.2018.11.050.

79. Zhang Q., PAN J., Jiang Y., Feng T., 2020, The impact of green supplier integration on firm performance: The mediating role of social capital accumulation, Journal of Purchasing and Supply Management, 26(2): 100579,

DOI: $10.1016 /$ j.pursup.2019.100579.

80. Zhang Q., CaO M., Zhang F., LiU J., Li X., 2020, Effects of corporate social responsibility on customer satisfaction and organizational attractiveness: A signaling perspective, Business Ethics: A European Review, 29(1): 20-34, DOI: 10.1111/beer.12243. 